\title{
Working
}

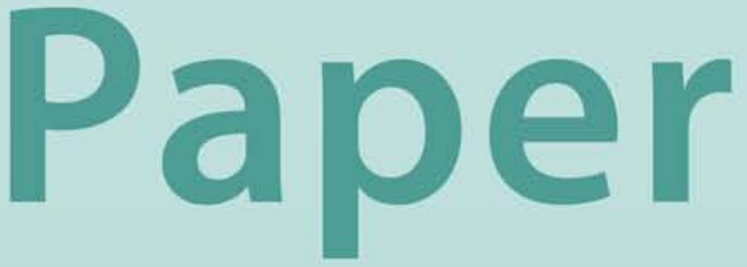




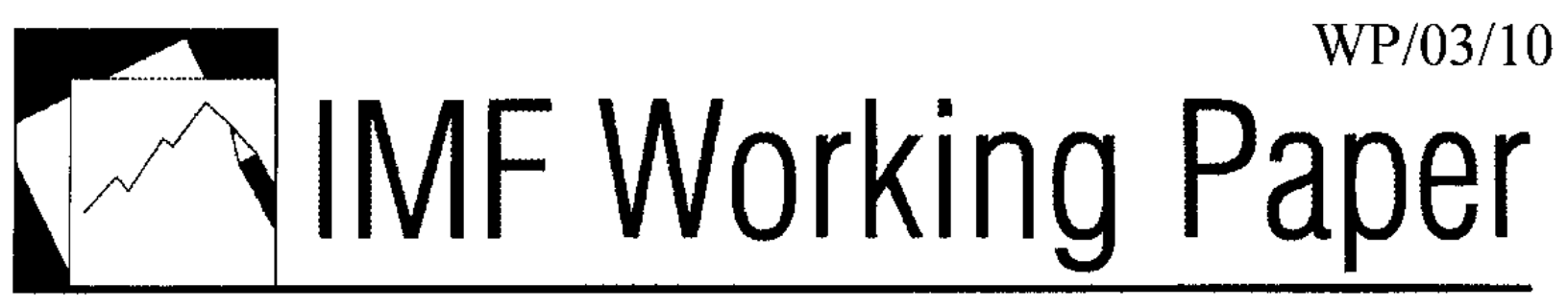

\section{FDI to Africa: \\ The Role of Price Stability and Currency Instability}

Kenneth Rogoff and Carmen Reinhart 


\title{
IMF Working Paper
}

Research Department

FDI to Africa:

The Role of Price Stability and Currency Instability

Prepared by Kenneth Rogoff and Carmen Reinhart ${ }^{1}$

January 2003

\begin{abstract}
The views expressed in this Working Paper are those of the author(s) and do not necessarily represent those of the IMF or IMF policy. Working Papers describe research in progress by the author(s) and are published to elicit comments and to further debate.
\end{abstract}

Africa lags behind other regions in attracting foreign direct investment (FDI). In some circumstances, there are obvious explanations for the absence of FDI, such as a high incidence of war. In this paper, we examine the role that monetary and exchange rate policy may have played in explaining this outcome. Specifically, we document the incidence of inflationary episodes and currency crashes in order to compare countries within the region as well as to make comparisons with other regions. Furthermore, since monetary policy can range from very transparent to very opaque, we assess Africa's track record with dual and parallel markets. We use the parallel market premia as an indicator of the degree of distortions and extent of transparency. Our findings suggest that this is a promising line of inquiry because Africa does stand apart from other regions in this measure of transparency. We also discuss some of the fiscal underpinnings of Africa's bouts with high inflation.

JEL Classification Numbers: F0, F4

Keywords: Parallel markets, inflation, capital controls, and conflict Authors' E-Mail Addresses: krogoff@imf.org; creinha 36878nt@imf.org

${ }^{1}$ This paper was prepared for the Annual World Bank Conference on Development Economics, Washington DC, April 29-30, 2002. The authors wish to thank Kenichiro Kashiwase, Daoude Sembene, and Ioannis Tokatlidis for superb research assistance and Vincent Reinhart for helpful comments and suggestions. 


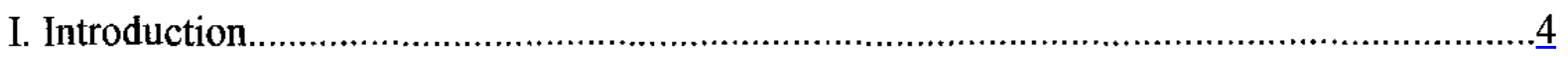

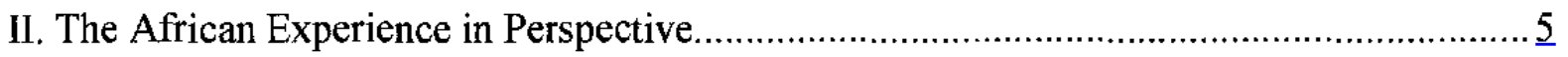

III. High Inflation, Currency Crashes, and FDI: Is Africa Different? $\underline{6}$

A. The Basics for Attracting FDI ............................................................

B. The Incidence of High Inflation and Currency Crashes ................................. 7

IV. Distortions and Lack of Transparency: The Role of Exchange Rate Arrangements $\quad \underline{14}$

A. The Prevalence of Dual Exchange Rates...................................................... 14

B. The Parallel Premia, Distortions, and Corruption ....................................... $\underline{15}$

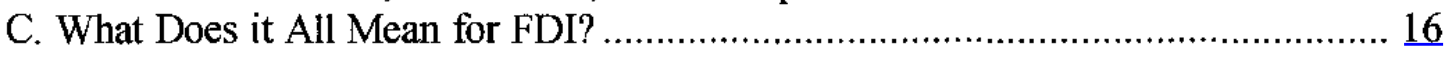

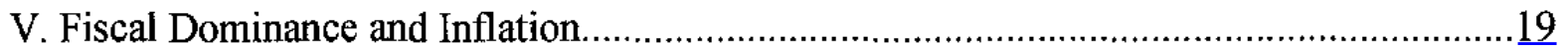

Text Tables

1. The Incidence of War: January 1960-December 2001...........................................

2. African Countries for Which the Average Inflation Rate During 1970-2001

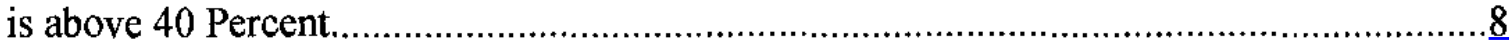

3. High Inflation Spells: North Africa and CFA Franc Zone, 1965-2001 ........................

4. High Inflation Spells: Sub Sahara non CFA Franc Zone, 1965-2001 ..........................10

5. High Inflation Spells: Asia, Europe, and Middle East, 1965-2001...............................11

6. High Inflation Spells: Western Hemisphere, 1965-2001 ......................................12

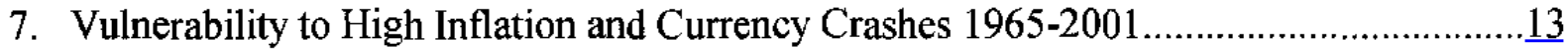

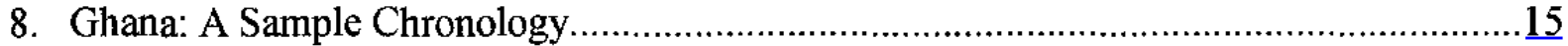

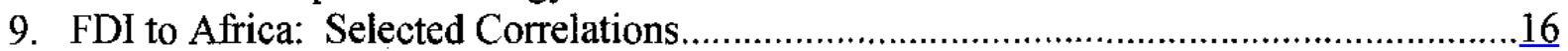

10. The Determinants of FDI: A Review of the Literature ............................................. 17

11. The Determinants of FDI: Regional Studies........................................................ 18

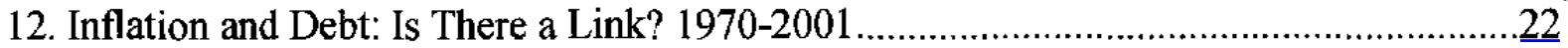

Figures

1. U.S. Monetary Policy and Capital Flows to Emerging Market Economies.....................24

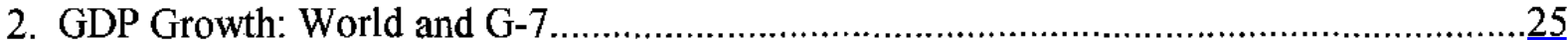

3. Africa: Inflation vs. Foreign Direct Investment (FDI) Inflow, 1970-2001...................26

4. Western Hemisphere: Inflation vs. Foreign Direct Investment (FDI) Inflow, 1970-2001

5. Percent of Months in Which the Parallel Market Premia Was Above 50 percent: 1979-98

6. Percent of Months in Which the Parallel Market Premia Was Above 500 percent: $1979-98$

7. Inflation and High Parallel Market Premia..........................................................

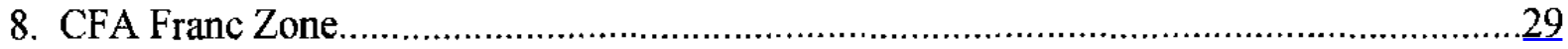


Appendix I.

Appendix Tables

13. Currency Crashes: North Africa and CFA Franc Zone Countries, 1965-2001 .................32

14. Currency Crashes: Sub-Saharan Africa Non CFA Franc Zone Countries, 1965-2001 $\underline{33}$

15. Currency Crashes: Asia, and Europe and Middle East, 1965-2001...............................

16. Currency Crashes: Western Hemisphere, 1965-2001..............................................35

17. Incidence of High Parallel Market Premium, Africa 1970-98: North Africa, CFA,

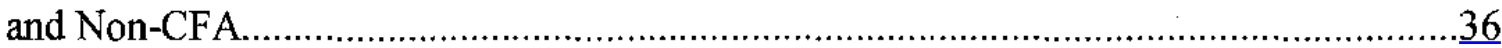

18. Incidence of High Parallel Market Premium, Asia, Europe, and the Middle East: 1970-98 .......................................................................

19. Incidence of High Parallel Market Premium, Western Hemisphere 1970-98_................38

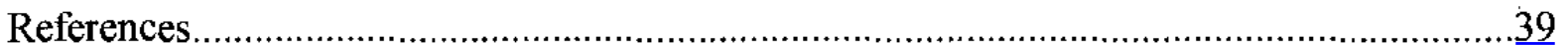




\section{INTRODUCTION}

Strong, stable macroeconomic policies are not sufficient conditions for investment and growth. Among many other important factors is the transparency of macroeconomic policies, robust institutions, low levels of corruption, absence of wars, openness to trade, and a favorable external environment. But macroeconomic policy stability-especially price stability-is almost certainly an essential ingredient. Without it, the risks to doing business rise drastically, internal trade is significantly hampered, and external trade even more so. High and unpredictable inflation, especially, cripples business planning and checks the development of financial intermediation within the private sector. Because this is well known, many countries throughout the world have strived to achieve notable success in bringing down inflation since the 1980s in the industrial countries and especially over the $1990 \mathrm{~s}$, in emerging markets and developing countries. The key to achieve this is well known and well proven: a strong, independent central bank that places a high weight on maintaining low inflation.

Whether this low inflation is attained through appointing skilled, highly competent central bankers who are known to be committed to price stability - the most common approach - or through a more complex institutionalized system of checks and balances-or both, is second order compared to maintaining true central bank independence.

Some have argued that this prescription cannot be transferred to sub-Saharan Africa because many countries in the region are in too early phases of political development. These countries, according to this argument, lack the necessary institutional structure to establish a truly independent central bank. If the judiciary and the parliament are unduly influenced by the chief executive or the rule of law is in some other ways indistinct, the central bank has nowhere to hide. In such circumstances, when the chief executive phones the head of the central bank and asks for funds, the central bank can hardly refuse. Because of these internal pressures, many African countries have sought to import price stability through joining a regional currency or joining a regional currency bloc anchored to a reserve currency, such as the euro or the dollar.

Aside from currency arrangements, many developing countries must, by necessity, put a high premium on attracting foreign direct investment. Yet, as Figure 1 illustrates, foreign direct investment (FDI) to Africa does not depend on whether the large economies, such as the United States, are in recession or not. Furthermore, Africa did not benefit much from the surge in FDI to emerging markets during the 1990s. How can these nations achieve the climate of price stability needed to facilitate investment?

This is a difficult question that we shall attempt to address by examining some essential features of the historical experience of Africa with inflation and exchange rate arrangements, drawing on the extensive chronologies developed in Reinhart and Rogoff (2002) - that encompass all countries of the world. This historical perspective yields some useful insights. First, the typical inflation and exchange rate experience in postcolonial, nonCFA Africa is weak compared with that of Europe and Asia. But, even excluding the more 
stable CFA franc zone countries, it is not notably worse than the experiences of many countries in Latin America, the Middle East, or post-1980s transition economies. This may seem like faint praise, since so many countries in these other regions have such a chequered inflation history. But it is relevant if one wants to argue that Africa needs a completely different set of arrangements than elsewhere. Secondly, we find that the incidence of extremely high parallel exchange market premia of 50 percent or more (exceeding 500 percent in some cases) is remarkably high in Africa, and herein lies the real differences. Averaging across all countries, between 1979 and 1998, the parallel market premia in nonCFA sub-Saharan Africa exceeded 50 percent more than one-third of the time! We argue that parallel market premia at this level are highly problematic, in that they breed significant corruption and governance problems. As such, they are often an excellent barometer of broader and deeper problems in macroeconomic stabilization and governance. The case for advocating unified exchange rate regimes rests as much on improving governance and reducing corruption as on any macroeconomic benefit. A third conclusion we reach is that adopting the currency of an industrial country has its own set of problems, not the astonishingly least frequent incidence of deflation.

The paper is divided into six parts, including this introduction. The second section of the paper briefly puts the postcolonial African exchange rate experience in perspective relative to Europe. The third section looks at the incidence of high inflation and the frequency of currency crashes in Africa compared to other regions. Here, our emphasis is on assessing the extent to which price and currency instability is behind the low observed levels of FDI. In our analysis of the behavior of parallel market premia in the fourth section, we find that the high probability of extremely large premia makes the African experience markedly different from the rest of the world. We argue that the high parallel premia may be symptomatic of more general governance problems in many cases, including corruption, and creating obstacles to trade- - with deleterious consequences for FDI. The fifth section of the paper offers some insights on the root cause of inflation from a broad theoretical perspective. This perspective suggests that the funding needs of the fiscal authority-that is-fiscal dominance - is likely to be a significant problem for many of the highly indebted African countries. The concluding section speculates on options for Africa in the light of the experience.

\section{The African Experience in Perspective}

Modern central banking is a relatively recent development. Only a couple of hundred years ago, few countries in the world had the governmental checks and balances needed to maintain an independent central bank. As a case in point, the central bank of Spain began in 1782 as the Bank of St. Charles, founded originally as a quasi-private bank by King Charles III of Spain. The unabashed purpose was to help absorb government debt. The name of the bank itself speaks volumes about how (not) independent it was from the chief executive. When King Ferdinand came to the throne, the Bank of St. Charles became the Bank of St. Ferdinand. Only much later did it become the Bank of Spain, which today, stands as a funding member of the nascent Euro-system. In the United States, efforts to sustain a national 
central bank failed twice during the nineteenth century. During that country's civil war of 1861-65, the Confederate states abandoned the Yankee dollar and printed their own confederate currency. Civil wars are not an unusual feature of a relatively young state, nor are their monetary consequences. The modern U.S. Federal Reserve System was established in 1913. But even during the first half of the twentieth century, the internal governance structures that helped to sustain its independence were less firmly established than they are today. In 1934, for example, the U.S. government invalidated gold contracts, and a few years later President Franklin D. Roosevelt seriously entertained expanding the United States Supreme Court from 9 members to 18 or 20 in order to stack the court with Justices who would support his programs. Eventually he abandoned this proposal, but the point is that even in relatively modern day experience, governance structures continued to evolve. Similar examples can be given across the industrial world. In that regard, the problems of Africa in establishing independent central banks are not unique to young nations, but the benefits can be great, and as modern central banking techniques continue to improve, there is a strong case to be made that improved monetary policy has been one factor in the greater stability of output and employment observed in many industrial countries since the $1980 \mathrm{~s}$. This part is illustrated dramatically in Figure 2, which gives year-to-year changes in growth rates for the G-7 (Japan is an exception) and the world. As is evident from the figure, and can be confirmed by closer statistical analysis, output volatility has been dropping dramatically since the mid-1980s. Thus, while high inflation is often a symptom rather than a cause of growth problems, it can also be a problem in its own right.

\section{High Inflation, Currency Crashes, ANd FDI: Is Africa Different?}

The aim of this section is descriptive, as we neither offer nor test a formal model of the determinants of FDI to Africa nor to any other region. ${ }^{2}$ We begin by looking at some of the possible "pull" factors that may influence FDI. As to "push" factors, Reinhart and Reinhart (2001) show that FDI to developing countries has an important cyclical component, more so than other types of capital flows. As a general rule, FDI flows more heavily to emerging market economies when the U.S. economy is expanding than when it is in recession. This cyclical pattern has important consequences for the volume of FDI that developing countries in Asia and Western Hemisphere receive, as illustrated in Figure 1. Yet, the cycle is not relevant for African economies, which generally receive very little FDI at any stage of the U.S. cycle. Indeed, looking at panel data on total capital flows to Africa, Calvo and Reinhart (1997) conclude that, in contrast to other regions, the only external factor that systematically influences capital flows to Africa is world commodity prices. Flows increase during booms in commodity prices and, other things being equal, decline during busts. In what follows, we document what could, in principle, be expected to be deterrents to investing in Africa.

${ }^{2}$ See Kamaly (2001) for an interesting new study and for a comprehensive survey of the empirical literature on the determinants of FDI. 


\section{A. The Basics for Attracting FDI}

An obvious and powerful deterrent to FDI is political instability. Edwards (1990) finds that the political instability is always statistically significant, irrespective of what other variables are included as regressors in his cross-country regressions. Of course, wars are an extreme form of political instability - and Africa has had more than its share. Using the dates of wars provided in Collier and Hoeffler (2001) and (2002), we constructed the probability of war for three regions, Africa, Asia, and Western Hemisphere (excluding Canada and the United States), over 1960-2001. This probability is simply the number of months during which there was a war over the total number of months for a particular country. We then average across countries to obtain the regional number. As shown in Table 1, the probability for Africa, at 12.6 percent, is almost twice as large as that of the developing Western Hemisphere but slightly below the number for Asia. However, column (3) paints a strikingly different picture- -40 percent of the countries in Africa have had at least one war during 1960-2001, 28 percent of the countries have had two or more. This is more than three times the incidence of war in Western Hemisphere and almost twice that of Asia. In the case of the latter, the higher probability shown in column (2) reflects that a smaller number of countries had longer wars.

While wars, per se, are a likely deterrent to FDI, wars also are often a source of another deterrent to FDI, inflation.

Table 1. The Incidence of War, January 1960-December 2001

\begin{tabular}{|l|c|c|c|}
\hline \multicolumn{1}{|c|}{ Region } & $\begin{array}{c}\text { Probability of war: Percent } \\
\text { of Months During Which } \\
\text { There Was Conflict } \\
\text { (1) }\end{array}$ & $\begin{array}{c}\text { Percent of Countries in the } \\
\text { Region with at Least One } \\
\text { War During the Sample } \\
\text { (3) }\end{array}$ & $\begin{array}{c}\text { Regional Susceptibility } \\
\text { to War Index: Average } \\
\text { of Columns (2) and (3) } \\
\text { (4) }\end{array}$ \\
\hline Africa & 12.6 & 40.0 & 26.3 \\
\hline Asia & 13.9 & 23.9 & 19.4 \\
\hline $\begin{array}{l}\text { Western Hemisphere } \\
\text { (excluding Canada } \\
\text { and United States) }\end{array}$ & 6.4 & 13.3 & 9.9 \\
\hline
\end{tabular}

Sources: Collier and Hoeffler (2001) and (2002) and authors' calculations

\section{B. The Incidence of High Inflation and Currency Crashes}

As a rule of thumb, we can take a 40 percent inflation rate over a 12 -month period as the threshold over which price instability becomes seriously dysfunctional. In Africa, there are five countries where the average annual inflation rate over the 1970-2001 period exceeded 40 percent. These are shown in Table 2 , alongside the probability of war, as measured by the percent of months during which there was conflict. For four of the five high- 
inflation cases, the probability of war was notably higher than for the rest of Africa. ${ }^{3}$ Furthermore, for those four cases, not only is inflation well above the average for the rest of the region-the probability of war is also well above the average for the remainder of the countries in the region.

Hence, it is an understatement to suggest that conflict, as well as the economic instability that it brings, can be expected to have deleterious consequences for the investment climate. For Africa, the cross-country correlation between the average inflation rate and the probability of war over the same period is 0.36 and is statistically significant. Apart from wars, however, inflation may also arise in peacetime when there is a problem of fiscal dominance - an issue that we take up later in greater detail.

Table 2. African Countries for Which the Average Inflation Rate During 1970-2001 is above 40 Percent

\begin{tabular}{|l|c|c|}
\hline \multicolumn{1}{|c|}{ Country } & $\begin{array}{c}\text { Average Annual Inflation, } \\
\mathbf{1 9 7 0 - 2 0 0 1}\end{array}$ & $\begin{array}{c}\text { Percent of Months During } \\
\text { Which There Was Conflict }\end{array}$ \\
\hline Congo, Dem. Rep. of the & $1,112.9$ & 30.3 \\
\hline Angola & 345.4 & 96.3 \\
\hline Uganda & 67.2 & 18.5 \\
\hline Ethiopia & 43.0 & 65.2 \\
\hline Zambia & 41.1 & 0.0 \\
\hline $\begin{array}{l}\text { Regional average excluding } \\
\text { Congo }\end{array}$ & 12.4 & 9.1 \\
\hline
\end{tabular}

Sources: International Monetary Fund, World Economic Outlook, Collier and Hoeffler (2001) and (2002) and authors' calculations.

Over and beyond these more extreme cases, Tables 3 to 6 document other countries' experiences with high inflation (above 40 percent). The tables provide information on the dates of high-inflation episodes and their average duration in years and months. ${ }^{4}$ The main results that emerge from the more detailed country-by-country analysis is summarized in Table 7, which gives the regional averages for the probability that the 12-month inflation rate is above 40 percent, as well as the average duration of the inflation spells. Table 7 also provides information on currency crashes, which we will discuss next. For North and CFA Africa, inflation is clearly not the critical issue, as these countries score well relative to other regions. For the CFA franc zone countries, which are pegged to the French franc, the more

${ }^{3}$ Indeed, as can be documented from the worldwide historical exchange rate chronologies in Reinhart and Rogoff (2002), the Democratic Republic of the Congo has experienced two hyperinflations since World War II. To date, no other country has had more than one.

${ }^{4}$ For an excellent review of the experiences with high inflation, see Végh (1992); and Fischer, Sahay, and Végh (2001). 
considerable problem has been deflation, as Reinhart and Rogoff (2002) document. The contrast that emerges from comparing non-CFA Africa to other regions is that Africa's inflation track record is far worse than Asia's track record. However, Africa's inflation performance is not that different from the average for developing Europe and the Middle East. Most notably, Africa has a better historical record than that of the inflation-prone Western Hemisphere. This is an important finding, as we already alluded to in the introduction. Africa's inflation record may not be strong, but it is not as exceptional as many have maintained. Therefore the extent to which special solutions are required should not be exaggerated.

Of course, it is worth noting that FDI to high-inflation Western Hemisphere region was also only a trickle during the $1980 \mathrm{~s}$, and that FDI only surged following the various efforts within many countries in the region to bring inflation under control. What these recent trends imply is that, going forward, Africa should focus on maintaining a climate of price stability.

Table 3. High-Inflation Spells: North Africa and CFA Franc Zone, 1965-2001

\begin{tabular}{|l|c|c|}
\hline \multicolumn{1}{|c|}{ Country } & $\begin{array}{c}\text { Episodes of Inflation Above } \\
\text { 40 Percent }\end{array}$ & $\begin{array}{c}\text { Total Number of Years and Months } \\
\text { with Inflation Above 40 Percent }\end{array}$ \\
\hline North Africa & & 13 months \\
\hline Algeria & $1994: 1-1995: 1$ & 4 months \\
\hline Morocco & & \\
\hline Tunisia & & 1 year \\
\hline North Africa average & & 1 year \\
\hline Sub-Saharan Africa, CFA & $1994: 1-1994: 12$ & 13 months \\
\hline Benin & & 13 months \\
\hline Burkina Faso & $1994: 1-1994: 12$ & 13 months \\
\hline Cameroon & $1994: 1-1995: 1$ & 1 year \\
\hline Central African Rep. & $1994: 1-1995: 1$ & 1 year \\
\hline Chad & $1994: 1-1995: 1$ & \\
\hline Congo, Rep. of & $1994: 1-1994: 12$ & \\
\hline Equatorial Guinea & $1994: 1-1994: 12$ & 1 year \\
\hline Gabon & & 11 months \\
\hline Guinea-Bissau & & 1 year \\
\hline Mali & $1994: 1-1994: 12$ & 9 months \\
\hline Niger & $1994: 1-1994: 11$ & \\
\hline Senegal & $1994: 1-1994: 12$ & \\
\hline Togo & & \\
\hline CFA franc zone average & & \\
\hline Sources: & & \\
\hline
\end{tabular}

Sources: International Monetary Fund, International Financial Statistics; Collier and Hoeffler (2002); Fischer, Sahay and Végh (2001); Mitchell (1982); and Reinhart and Rogoff (2002). 
Table 4. High-Inflation Spells: Sub Sahara non-CFA Franc Zone, 1965-2001

\begin{tabular}{|c|c|c|}
\hline Country & $\begin{array}{c}\text { Episodes of Inflation Above } \\
40 \text { Percent }\end{array}$ & $\begin{array}{c}\text { Total Number of Years and Months with } \\
\text { Inflation Above } 40 \text { Percent }\end{array}$ \\
\hline Angola & $1991: 3-2001: 12$ & 10 years, 9 months \\
\hline Burundi & $\begin{array}{l}1978: 1-1979: 7 \\
1996: 5-1997: 5\end{array}$ & 1 year, 6 month \\
\hline Congo, Dem. Rep. of & $\begin{array}{l}1967: 1-1968: 9 \\
1975: 1-1984: 8 \\
1987: 2-1997: 11 \\
\end{array}$ & 21 years, 6 months \\
\hline Ethiopia & $1990: 6-1991: 7$ & 13 months \\
\hline Gambia, The & $1985: 1-1987: 2$ & 2 years, 1 month \\
\hline Ghana & $\begin{array}{l}1973: 10-1984: 5 \\
1986: 4-1987: 9 \\
1989: 8-1990: 9 \\
1994: 3-1996: 8 \\
1999: 11-2001: 4\end{array}$ & 15 years, 11 months \\
\hline Guinea & $1986: 1-1986: 12$ & 1 year \\
\hline Kenya & $1992: 9-1994: 3$ & 2 years, 1 month \\
\hline Madagascar & $\begin{array}{l}1947: 1-1948: 12 \\
1994: 1-1995: 8\end{array}$ & 2 years, 7 months \\
\hline Malawi & 1993:11-1996:6 & 2 years, 7 months \\
\hline Mozambique & $1993: 6-1995: 7$ & 2 years, 1 month \\
\hline Nigeria & $\begin{array}{l}1983: 4-1984: 9 \\
1987: 2-1989: 12 \\
1991: 6-1996: 3\end{array}$ & 9 years \\
\hline \multicolumn{3}{|l|}{ Rwanda } \\
\hline Somalia & $\begin{array}{l}1978: 11-1981: 6 \\
1982: 7-1986: 8 \\
1987: 2-1989: 11\end{array}$ & 9 years, 5 months \\
\hline Sudan & $\begin{array}{l}1978: 11-1980: 2 \\
1980: 8-1981: 8 \\
1983: 9-1985: 6 \\
1986: 10-1997: 4\end{array}$ & 14 years, 6 months \\
\hline \multicolumn{3}{|l|}{ South Africa } \\
\hline \multicolumn{3}{|l|}{ Swaziland } \\
\hline Tanzania & $\begin{array}{l}1983: 4-1985: 3 \\
1992: 6-1995: 3\end{array}$ & 7 years, 8 months \\
\hline Uganda & $\begin{array}{l}1981: 1-1982: 5 \\
1983: 8-1990: 4\end{array}$ & 8 years \\
\hline Zambia & $1985: 1-1996: 9$ & 11 years, 8 months \\
\hline Zimbabwe & $\begin{array}{l}1991: 5-1993: 2 \\
1997: 12-1999: 12\end{array}$ & 3 years, 10 months \\
\hline Non-CFA franc zone average & & 6 years, 7 months \\
\hline
\end{tabular}

Sources: International Monetary Fund, International Financial Statistics; Collier and Hoeffler (2002); Fischer, Sahay and Végh (2001); Mitchell (1982); and Reinhart and Rogoff (2002).

Notes: Hyper-inflation refers to Cagan's definition - a hyperinflation begins in the month the rise in prices exceeds 50 percent and ending in the month the monthly rise in prices drops below that amount and stays below. See Fischer, Sahay, and Végh (2001) for a recent discussion of hyperinflations. 
Table 5. High-Inflation Spells: Asia, Europe, and Middle East, 1965-2001

\begin{tabular}{|c|c|c|}
\hline Country & $\begin{array}{c}\text { Episodes of Inflation Above } \\
40 \text { Percent }\end{array}$ & $\begin{array}{c}\text { Total Number of Years and Months } \\
\text { with Inflation Above } 40 \text { Percent }\end{array}$ \\
\hline \multicolumn{3}{|l|}{ Asia } \\
\hline \multicolumn{3}{|l|}{ China } \\
\hline \multicolumn{3}{|l|}{ Hong Kong SAR } \\
\hline \multicolumn{3}{|l|}{ India } \\
\hline Indonesia & $\begin{array}{l}1972: 7-1974: 6 \\
1997: 7-1999: 3\end{array}$ & 2 years, 9 months \\
\hline \multicolumn{3}{|l|}{ Korea } \\
\hline Lao People's Dem. Rep. & $\begin{array}{l}1988: 6-1990: 4 \\
1997: 4-2000: 2\end{array}$ & 3 years, 11 months \\
\hline \multicolumn{3}{|l|}{ Malaysia } \\
\hline Myanmar & $\begin{array}{l}1972: 8-1976: 2 \\
1988: 4-1989: 5 \\
1990: 5-1991: 5 \\
1993: 1-1994: 1 \\
1996: 8-1999: 1\end{array}$ & 9 years \\
\hline \multicolumn{3}{|l|}{ Nepal } \\
\hline \multicolumn{3}{|l|}{ Pakistan } \\
\hline Philippines & 1984:4-1985:2 & 10 months \\
\hline \multicolumn{3}{|l|}{ Singapore } \\
\hline \multicolumn{3}{|l|}{ Sri Lanka } \\
\hline \multicolumn{3}{|l|}{ Thailand } \\
\hline Asia average & & 1 year, 2 months \\
\hline \multicolumn{3}{|l|}{ Europe and Middle East } \\
\hline \multicolumn{3}{|l|}{ Egypt } \\
\hline Iceland & $\begin{array}{l}1973: 5-1976: 1 \\
1977: 5-1984: 5\end{array}$ & 9 years, 8 months \\
\hline Iran, I. S. of & $1994: 2-1996: 2$ & 2 years \\
\hline \multicolumn{3}{|l|}{ Iraq } \\
\hline Israel & $\begin{array}{l}1951: 1-1951: 12 \\
1973: 10-1986: 12\end{array}$ & 14 years, 2 months \\
\hline \multicolumn{3}{|l|}{ Jordan } \\
\hline Lebanon & $1984: 3-1993: 3$ & 9 years \\
\hline \multicolumn{3}{|l|}{ Libya Arab Rep. } \\
\hline Poland & $1988: 1-1992: 12$ & 4 years, 11 months \\
\hline Romania & $1990: 10-2001: 3$ & 11 years, 5 months \\
\hline \multicolumn{3}{|l|}{ Saudi Arabia } \\
\hline Turkey & $\begin{array}{l}1976: 9-1981: 3 \\
1983: 4-2001: 12\end{array}$ & 22 years, 2 months \\
\hline Europe and Middle East average & & 6 years, 1 month \\
\hline
\end{tabular}

Sources: International Monetary Fund, International Financial Statistics; Collier and Hoeffler (2002); Fischer, Sahay, and Végh (2001); Mitchell (1982); and Reinhart and Rogoff (2002) 
Table 6. High-Inflation Spells: Western Hemisphere, 1965-2001

\begin{tabular}{|c|c|c|}
\hline Country & $\begin{array}{c}\text { Episodes of Inflation Above } \\
40 \text { Percent }\end{array}$ & $\begin{array}{l}\text { Total Number of Years and Months } \\
\text { with Inflation Above } 40 \text { Percent }\end{array}$ \\
\hline Argentina & $1970: 8-1992: 2$ & 21 years, 6 months \\
\hline Bolivia & $\begin{array}{l}1972: 9-1974: 12 \\
1978: 12-1986: 12\end{array}$ & 10 years, 6 months \\
\hline Brazil & $1980: 1-1995: 5$ & 16 years, 4 months \\
\hline Chile & 1971:5-1978:6 & 7 years, 1 month \\
\hline Costa Rica & $1980: 9-1983: 6$ & 2 years, 9 months \\
\hline Dominican Republic & $\begin{array}{l}1984: 1-1985: 11 \\
1987: 7-1989: 6 \\
1989: 8-1991: 8\end{array}$ & 5 years, 9 months \\
\hline Ecuador & $\begin{array}{l}1982: 5-1984: 4 \\
1987: 4-1993: 8 \\
1997: 10-2001: 4\end{array}$ & 9 years, 11 months \\
\hline Guatemala & $\begin{array}{l}1985: 3-1986: 6 \\
1989: 6-1991: 4\end{array}$ & 3 years, 1 month \\
\hline Guyana & 1988:1-1991:12 & 3 years, 11 months \\
\hline Haiti & 1993:5-1995:1 & 1 year, 8 months \\
\hline Jamaica & $\begin{array}{l}1977: 7-1979: 4 \\
1990: 7-1992: 12\end{array}$ & 4 years, 2 months \\
\hline Mexico & $\begin{array}{l}1981: 5-1988: 12 \\
1994: 12-1996: 1\end{array}$ & 8 years, 8 months \\
\hline Nicaragua & $\begin{array}{l}1978: 6-1980: 5 \\
1982: 8-1992: 2\end{array}$ & 9 years, 6 months \\
\hline Paraguay & $\begin{array}{l}1985: 4-1986: 4 \\
1989: 5-1991: 1\end{array}$ & 2 years, 1 month \\
\hline Peru & 1975:9-1993:11 & 18 years, 2 month \\
\hline Suriname & $\begin{array}{l}1986: 5-1987: 12 \\
1991: 5-1995: 11\end{array}$ & 6 years, 1 month \\
\hline Uruguay & $\begin{array}{l}1962: 12-1969: 1 \\
1972: 1-1981: 1 \\
1982: 2-1995: 9\end{array}$ & 24 years, 6 months \\
\hline Venezuela & $1988: 2-1997: 7$ & 9 years, 5 months \\
\hline Western Hemisphere average & & 9 years, 6 months \\
\hline
\end{tabular}

Sources: International Financial Statistics, International Monetary Fund, Collier and Hoeffler (2002), Fischer, Sahay, and Végh (2001); Mitchell (1982); and Reinhart and Rogoff (2002).

Notes: Hyper-inflation refers to Cagan's definition-a hyperinflation begins in the month the rise in prices exceeds $50 \%$ and ending in the month the monthly rise in prices drops below that amount and stays below. See Fischer, Sahay and Végh (2001) for a recent discussion of hyperinflations. 
Table 7. Vulnerability to High Inflation and Currency Crashes, 1965-2001

\begin{tabular}{|l|c|c|c|c|}
\hline Region or Group & $\begin{array}{c}\text { Probability of Having } \\
\text { Inflation Greater } \\
\text { Than 40 Percent } \\
\text { (In percent) } \\
(\mathbf{1})\end{array}$ & $\begin{array}{c}\text { Average Duration } \\
\text { of Spells Where } \\
\text { Inflation Is Above } \\
\text { 40 Percent } \\
\text { (2) }\end{array}$ & $\begin{array}{c}\text { Probability of a } \\
\text { Severe Currency } \\
\text { Crash in Any 24 } \\
\text { Month Period } \\
(\mathbf{3})\end{array}$ & $\begin{array}{c}\text { Probability of a } \\
\text { Currency Crash } \\
\text { in any 24 Month } \\
\text { Period } \\
\text { (4) }\end{array}$ \\
\hline North Africa & 1.0 & 4 months & 5.4 & 7.2 \\
\hline $\begin{array}{l}\text { Sub-Saharan } \\
\text { Africa, CFA }\end{array}$ & 2.1 & 9 months & 5.4 & 5.4 \\
\hline $\begin{array}{l}\text { Sub-Saharan } \\
\text { Africa, Non-CFA }\end{array}$ & 17.8 & 6 years, 7months & 32.4 & 48.6 \\
\hline Asia & 3.2 & 1 year, 2months & 12.4 & 23.8 \\
\hline $\begin{array}{l}\text { Europe and } \\
\text { Middle East }\end{array}$ & 16.4 & 6 years, 1 month & 20.5 & 36.8 \\
\hline $\begin{array}{l}\text { Western } \\
\text { Hemisphere }\end{array}$ & 25.6 & 9 years, 6 months & 32.4 & 48.6 \\
\hline
\end{tabular}

Sources: Tables 1-4 and Appendix Tables 14-19.

Another manifestation of uncertainty that can be expected to affect the investment climate is the incidence of currency crashes - which is, of course, intimately related to the inflation performance. Since the CFA franc zone has had a long history of a stable exchange rate versus the French franc first and now versus the euro, we now turn out attention to documenting currency crashes for, mostly, the non-CFA countries. ${ }^{5}$

As we discuss in Section IV, it has been a common practice in many African countries to peg the official exchange rate to some anchor currency (often the U.S. dollar). Sometimes this was done in the context of dual markets, and sometimes in the context of an inflation stabilization plan. Some of these currency crashes, however, did not take place against the backdrop of a pegged official exchange rate but, rather, against a backdrop of a loss of monetary control.

To compare Africa's performance in this dimension with that of other regions, we constructed two measures of currency crashes, that are very similar to those introduced by Frankel and Rose (1996). The first of these definitions of currency crashes measures a "severe" currency crash, which refers to a 25 percent or higher monthly depreciation which is, in turn, at least 10 percent higher than the previous month's depreciation. The "milder" version represents a

${ }^{5}$ The one-time 100 percent devaluation for the franc zone countries on January 1994 is a well-known rare event that merits relatively little discussion in the context of exchange rate uncertainty. For the CFA franc zone, again, the high incidence of deflation we referred to earlier, has been much more of an issue. 
12.5 percent monthly depreciation that is at least 10 percent above the preceding month's depreciation. To put these magnitudes in perspective, monthly depreciations of this magnitude, when annualized, amount to 1,355 and 310 percent, respectively.

Columns (3) and (4) in Table 7 present regional averages, while Appendix Tables 14-17 give the individual country particulars. Not surprisingly, the regional patterns that emerge are very similar to those of the high inflation episodes. Africa (excluding CFA and North Africa) has a similar propensity to crash as Western Hemisphere, and both regions compare poorly to Asia and the other regions. Currency instability, as measured by frequent currency crashes, is strongly linked to poor inflation performance, and ex ante it can be expected that neither is conducive to a favorable inflation climate. Indeed, Kamaly (2001), who covers a panel of 151 countries over the 1990 to 1999 , presents systematic evidence that that such exchange rate volatility has a significant adverse impact on FDI flows.

However, this discussion has only focused on the inflation and exchange rate crisis outcomes of monetary policy. A dimension of monetary policy that would also be expected to influence investment decisions is the transparency (or lack thereof) of the policy arrangement - an issue examined in the next section.

\section{Distortions and Lack of Transparency: The Role of Exchange Rate ARRANGEMENTS}

Dual markets and multiple exchange rates are-by far-the least transparent form of exchange rate arrangement. Usually, although not always, dual rates are accompanied by a variety of restrictions on capital movements. If there is (in principle) a dual market, but capital flows freely (as was the case in Belgium up until 1990 and the CFA zone until 1993), the free market premium tends to be trivially small. However, when there are tight capital account restrictions, dual markets can really have teeth and the free market premia can be astonishingly high. Under these conditions, and especially if there are multiple exchange rates, monetary policy is at its most opaque. It is typically also in this kind of arrangement that corruption can flourish with a vengeance.

\section{A. The Prevalence of Dual Exchange Rates}

Reinhart and Rogoff's (2002) reclassification of historical exchange rate arrangements recognizes that the official exchange rate can be meaningless in this setting and that dual or multiple exchange rate practices need to be treated as a separate category. To do so, we constructed detailed chronologies - such as the sample shown Table 8 for Ghana. The episodes labeled "freely falling" are the instances when the 12-month inflation rate was above 40 percent, what we have called here "high-inflation" episodes. ${ }^{6}$ The chronology also notes when dual or multiple exchange rate practices are in place.

\footnotetext{
${ }^{6}$ See Reinhart and Rogoff (2002) for a detailed description of the classification strategy.
} 
Table 8. Ghana: A Sample Chronology

\begin{tabular}{|c|c|c|}
\hline Date & $\begin{array}{c}\text { Classification } \\
\text { Primary/Secondary/Tertiary }\end{array}$ & Comments \\
\hline 1916-July 14,1958 & Currency board/peg to pound sterling & $\begin{array}{l}\text { West African pound is introduced by the } \\
\text { West Africa Currency Board. }\end{array}$ \\
\hline July 14, 1958-July 19, 1965 & Peg to pound sterling/parallel market & $\begin{array}{l}\text { Ghana pound replaces the West African } \\
\text { Pound }\end{array}$ \\
\hline July 19,1965 -November 4,1971 & Peg to pound sterling/parallel market & $\begin{array}{l}\text { The cedi replaced the Ghana pound. The new } \\
\text { cedi was introduced in } 1967 \text {. }\end{array}$ \\
\hline November 4, 1971-September 1973 & Managed floating/parallel market & The cedi is officially pegged to U.S. dollar. \\
\hline October $1973-$ June 19,1978 & $\begin{array}{l}\text { Freely falling/managed } \\
\text { floating/parallel market }\end{array}$ & $\begin{array}{l}\text { The cedi is officially pegged to U.S. dollar. } \\
\text { There are multiple exchange rates. }\end{array}$ \\
\hline June 19, 1978-May 1984 & $\begin{array}{l}\text { Freely falling/managed } \\
\text { floating/parallel market }\end{array}$ & $\begin{array}{l}\text { The official peg to the U.S. dollar is } \\
\text { abandoned. There are multiple exchange } \\
\text { rates. }\end{array}$ \\
\hline June 1984-April 1986 & Freely floating/parallel market & There are multiple exchange rates. \\
\hline May 1986-September 19, 1986 & $\begin{array}{l}\text { Freely falling/freely floating/parallel } \\
\text { market }\end{array}$ & There are multiple exchange rates. \\
\hline September 19, 1986-September 1987 & $\begin{array}{l}\text { Freely falling/freely floating/dual } \\
\text { market }\end{array}$ & There are multiple exchange rates. \\
\hline October I987-July 1989 & Freely floating/dual market & There are multiple exchange rates. \\
\hline August 1989-April 27, 1990 & $\begin{array}{l}\text { Freely falling/managed floating/dual } \\
\text { market }\end{array}$ & There are multiple exchange rates. \\
\hline April 27, 1990-September 1990 & Freely falling/managed floating & There are multiple exchange rates. \\
\hline October 1990-February 1994 & Managed floating & $\begin{array}{l}\text { There are multiple exchange rates. Since } \\
\text { early } 1993, \text { the parallel market premia has } \\
\text { been in single digits. }\end{array}$ \\
\hline March 1994-July 1996 & Freely falling/managed floating & \\
\hline August 1996-October 1999 & Managed floating & \\
\hline November $1999-$ March 2001 & Freely falling/managed floating. & \\
\hline April 2001-December 2001 & Managed floating & \\
\hline
\end{tabular}

Notes: Formerly Gold Coast. Reference currencies are the U.S. dollar, the pound sterling, and the South African rand.

The downside of this opaque type of arrangement has not been trivial for Africa. Easterly (2001) has stressed the negative contribution to growth of high parallel market premia. Reinhart and Rogoff (2002) also present evidence that growth is lower and inflation higher for dual or multiple exchange rate arrangements. Yet, in Africa dual or multiple exchange rate arrangements account for about 32 percent of all observations (by country, by month) in the 1970-2001 period.

\section{B. The Parallel Premia, Distortions, and Corruption}

Appendix Tables 9-11 document the likelihood that the monthly parallel market premia exceed three high thresholds. While a 50 percent premia would be considered already high, we also document the incidence of the probability-by country and region-that the premia exceeds 100 and 500 percent. Figures 5 and 6 provide a cross-regional comparison. The main point that emerges from this exercise is that to the extent that the premia is a catchall for distortions, lack of transparency, and corruption, non-CFA Africa stands out from other regions by the extremely high incidence of very high premia. Even relative to the chronic-inflation crisis prone Western Hemisphere, the comparison is striking. The likelihood of premia above 50 percent is 35 and 23 percent for Africa and Western Hemisphere, 
respectively. Premia above the 100 percent threshold prevail in 25 percent of the months during 1970-1998 in Africa-more than twice that for Western Hemisphere, while premia over 500 percent are present in 10 percent of the months.

An interesting exercise involves looking jointly at (a) the probability that the premia is above 50 percent over 1970-1998 for each of the countries in our sample, and (b) the corruption index published by Transparency International for 2000 , which assigns a value of zero to the most corrupt countries and a value of ten to the most transparent. The simple pairwise correlation between the two is 0.55 , which is statistically significant at standard confidence levels-indeed, this simple exercise may suggest that the ranking of countries by their transparency exhibits considerable inertia. ${ }^{7}$

\section{What Does it All Mean for FDI?}

We have suggested that the investment climate is adversely influenced by actual wars - or the odds of a war. Wars, in turn, apart from the destruction of life and infrastructure, seem to bring additional deterrents to investment, such as frequent currency crashes and high inflation. Even when not accompanied by war, the prospects of price and currency instability during peacetime are not conducive to FDI. Furthermore, high parallel market premia, which are a proxy for distortions, inconsistent policies, and corruption, affect investment adversely. Table 9 presents a family of simple pairwise correlations to summarize these points, while Tables 10 and 11 present a synopsis of the literature on the empirical determinants of FDI. At first glance, our findings seem to depart strikingly from those of Gastanaga and others (1998), who find no evidence that the parallel market premia influences FDI. Of course, one interpretation of our contrasting results that merits further scrutiny is that they have a separate variable controlling for corruption. As shown in Table 9, the premia are correlated with this type of index, suggesting that the results are not necessarily inconsistent-all the more so if, as we contend, lack of transparency breeds corruption.

Table 9. FDI to Africa: Selected Correlations

\begin{tabular}{|l|l|}
\hline FDI and conflict & $-0.31^{*}$ \\
\hline FDI and inflation: CFA countries & $-0.23^{*}$ \\
\hline FDI and inflation: Non-CFA countries & $-0.17^{* *}$ \\
\hline $\begin{array}{l}\text { FDI and the probability that the parallel market premia } \\
\text { is above 50 percent }\end{array}$ & $-0.36^{*}$ \\
\hline Memorandum item: & \\
\hline Parallel market premia and corruption index & $-0.54^{*}$ \\
\hline
\end{tabular}

Notes: An asterisk $\left(^{*}\right)$ denotes significance at the 5 percent level, while a double asterisk (**) indicates significance at the 10 percent level.

${ }^{7}$ The transparency index was not published prior to 2000 and our data on the parallel market rate ends in 1998. 
Table 10. The Determinants of FDI: A Review of the Literature

\begin{tabular}{|c|c|c|c|c|}
\hline \multirow[t]{2}{*}{ Stuty } & \multirow[t]{2}{*}{ Sample } & \multicolumn{2}{|l|}{ Variables } & \multirow[t]{2}{*}{ Main Results } \\
\hline & & Endogenous Variable & Explanatory Variable & \\
\hline $\begin{array}{l}\text { Scluneider and } \\
\text { Frey (1985) }\end{array}$ & $\begin{array}{l}54 \text { developing countries for } \\
3 \text { different years ( } 1976 \text {, } \\
1979 \text {, and 1980). }\end{array}$ & FDI & $\begin{array}{l}\text { Economic determinants; real per capita GNP, } \\
\text { GNP growth, inflation, balance of payments } \\
\text { deficit, sccondary education enrollment and } \\
\text { bilateral aid from Western countries. Political } \\
\text { determinants: political instability and a dummy } \\
\text { for Icfl-wing regime. }\end{array}$ & $\begin{array}{l}\text { Two models were estimaled. One included both economic and political } \\
\text { dcterminants of FDI and the other included only cconomic determinants. The } \\
\text { former model gave better results and the best forccasting errors. }\end{array}$ \\
\hline Fdwards (1972) & $\begin{array}{l}58 \text { developing countries } \\
\text { covcring the pcriod } 1971- \\
81 \text {. Amuual data. }\end{array}$ & $\begin{array}{l}\text { Average ratio of OECD FDI } \\
\text { hows to country } i \text { to total } \\
\text { OECD FDl flows to } \\
\text { developing countries and FDI } \\
\text { to GDP. }\end{array}$ & $\begin{array}{l}\text { Real per capita income, size of government, } \\
\text { openness, real exchange rate, real GDP, domestic } \\
\text { investment ratio, structure of the cconomy, } \\
\text { regional dummies and political variables } \\
\text { (Stability and polarization). }\end{array}$ & $\begin{array}{l}\text { Variable were averages for the period covered. All variables were significant } \\
\text { and with the expected sign except for per capita income which was } \\
\text { insignificant. Both economic and political variables arc important in } \\
\text { determining the magnitude and the distribution of FDI but political variables } \\
\text { wcre not as crucial as the economic ones. }\end{array}$ \\
\hline $\begin{array}{l}\text { Singh and Jun } \\
(1995)\end{array}$ & $\begin{array}{l}31 \text { dcveloping countries for } \\
\text { the period } 1970-93 \text {. Annual } \\
\text { data. }\end{array}$ & FDI & $\begin{array}{l}\text { Sociopolitical instability, business operating } \\
\text { conditions, international trade variables and other } \\
\text { control variablc. }\end{array}$ & $\begin{array}{l}\text { Not all the control variables were found significant. Sociopolitical instability, } \\
\text { business operating conditions, international trade variables were found } \\
\text { important factor in driving flows cspccially lo high FDI countries. }\end{array}$ \\
\hline $\begin{array}{l}\text { Gastanaga, } \\
\text { Nugent and } \\
\text { Pashamova } \\
(1998)\end{array}$ & $\begin{array}{l}49 \text { developing countries for } \\
\text { the period } 1970-95 \text {. Annual } \\
\text { data. }\end{array}$ & Gross FDI flows to GDP. & $\begin{array}{l}\text { Lagged and future real GDP growlh, black } \\
\text { market exchange rate premium (BMP), the } \\
\text { degree of openness to capital flows and FDI, } \\
\text { lagged dependent variable, and othor variables } \\
\text { capturing coumtry reforms and the degree of } \\
\text { corruption. }\end{array}$ & $\begin{array}{l}\text { BMP was found to have little effect on FDI. Economic growth has significant } \\
\text { effect on FDI. Corruption and corporate tax both have negative and significant } \\
\text { effect on FDI. The cffect of tariff varies with the model specification. }\end{array}$ \\
\hline $\begin{array}{l}\text { Fernandez-Arias } \\
\text { and Haumann } \\
(2000 \mathrm{~b})\end{array}$ & $\begin{array}{l}\text { All countries where data } \\
\text { was available for the period } \\
\text { 1996-98. Simple average } \\
\text { was used. }\end{array}$ & $\begin{array}{l}\text { Total commercial flows to } \\
\text { GDP, FDI to commercial } \\
\text { flows and FDI to GDP. }\end{array}$ & $\begin{array}{l}\text { Variables capturing institutional infrastructure, } \\
\text { political stability and economic policies together } \\
\text { with } 3 \text { control variables; income, size and } \\
\text { openncss. }\end{array}$ & $\begin{array}{l}\text { In general, capital flows are drawn to countries with sound financial markets, } \\
\text { capable institutions and sound political environment. The high share of FDI as } \\
\text { a percentage of capital flows is not nccessary and indicative of "good health." } \\
\text { Higher share of FDI is associated with riskier and financially underdeveloped } \\
\text { countries with weaker institutional structure. }\end{array}$ \\
\hline Wei (2001) & $\begin{array}{l}59 \text { to } 93 \text { borrowing } \\
\text { countries depending on the } \\
\text { endogenous variable for the } \\
\text { period } 1994-96 \text {. Simple } \\
\text { average was used. }\end{array}$ & $\begin{array}{l}\text { Bilateral FDI compiled by } \\
\text { OECD, bank lending, log } \\
\text { ratio of loans to FDI, log } \\
\text { ration of portfolio investment } \\
\text { to FDI and FDI to total } \\
\text { inflows. }\end{array}$ & $\begin{array}{l}\text { For FDI regressions: Corruption, tax rate, FDl } \\
\text { incentives, FDI restrictions, log GDP, log per } \\
\text { capita GDP, log distance, linguistic tie and } \\
\text { exchange rate volatility. For regressions } \\
\text { involving porifolio investment and loans: same } \\
\text { variables but substituting a variable capturing the } \\
\text { case in investing in securities and bond market } \\
\text { instead of FDI restrictions and incentives } \\
\text { variables and dropping as well the tax variable. }\end{array}$ & $\begin{array}{l}\text { Mainly two exercises. The first tests the effect of corruption on FDI and the } \\
\text { second tests the effect of corruption on the composition of capital flows. } \\
\text { Fixed-effects and random-effects specifications were used. In case of the first } \\
\text { cxcrcise, the majority of variables were and with the expected signs. } \\
\text { Comruption has a very significant negative effect on FDI. Second excrcise } \\
\text { reveals that the highcr is the corruption, the more is the composition of capital } \\
\text { flows tilts toward more bank loans and portfolio flows and less of FDI. Results } \\
\text { were found robust to the change in the sample period to } 1997-98 \text {. }\end{array}$ \\
\hline $\begin{array}{l}\text { Wheeler and } \\
\text { Mody (1992) }\end{array}$ & $\begin{array}{l}\text { U.S. investment in abroad } \\
\text { by country }\end{array}$ & $\begin{array}{l}\text { Actual and planned } \\
\text { expenditure abroad by U.S. } \\
\text { companies. }\end{array}$ & $\begin{array}{l}\text { Foreign investment is regressed against labor } \\
\text { cost, corporate taxation and agglomeration } \\
\text { bencfit indices such as infrastructure quality, the } \\
\text { level of FDI and degree of industriulization. } \\
\text { Various measures of risk and openness were also } \\
\text { used. }\end{array}$ & $\begin{array}{l}\text { The classical variables (labor cost and markct size) werc statistically } \\
\text { significant as wcre the three agglomeration indices. The results for the other } \\
\text { indices were much more sensitive to the specification chosen. }\end{array}$ \\
\hline
\end{tabular}

Sources: Exccrpts from Kamaly (2001) and the authors. 
Table 11. The Determinants of FDI: Regional Studies

\begin{tabular}{|c|c|c|c|c|}
\hline \multirow[t]{2}{*}{ Sindy } & \multirow[t]{2}{*}{ Sample } & \multicolumn{2}{|l|}{ Variables } & \multirow[t]{2}{*}{ Estimation Technique and Main Results } \\
\hline & & Endogenous Variable & Explanatory Variable & \\
\hline Torrisi (1985) & $\begin{array}{l}\text { Colombia for the period } \\
1958-80 \text {. Annual data. }\end{array}$ & FDI and total U.S. FDI. & $\begin{array}{l}\text { Real GDP, growth rate of GDP, lag trade balance } \\
\text { and a dummy capturing the establishment of a trade } \\
\text { block. }\end{array}$ & $\begin{array}{l}\text { GDP coefficient was found to be significant together } \\
\text { with trade balance but the latter took a negative sign. }\end{array}$ \\
\hline $\begin{array}{l}\text { Bathattachrya, } \\
\text { Montiel, and } \\
\text { Sharma (1997) }\end{array}$ & $\begin{array}{l}15 \text { Sub-saharan African } \\
\text { countries for the period } \\
1980-95 \text {. Annual data. }\end{array}$ & $\begin{array}{l}\text { Private flows, FDI, private } \\
\text { loans all as a percent of } \\
\text { GDP. }\end{array}$ & $\begin{array}{l}\text { Lag growth rate of GDP, lag gross fixed capital } \\
\text { formation to GDP, lag exports plus imports to GDP, } \\
\text { lag total external debt to GDP, coefficient of } \\
\text { variation of monthly real effective exchange rate } \\
\text { index, lagged endogenous variable, and U.S. } 3 \text { year } \\
\text { government bond yield. }\end{array}$ & $\begin{array}{l}\text { Panel analysis was used. For private flows all variables } \\
\text { were significant with expected signs except real } \\
\text { exchange rate variability. For FDI key variables were } \\
\text { GDP growth, openness and variability of exchange } \\
\text { rate. For private loans key factors were domestic } \\
\text { investment and external debt ratios. U.S. interest was } \\
\text { found not to be significant in any of the regressions. }\end{array}$ \\
\hline $\begin{array}{l}\text { Claessens et al. } \\
\text { (1999) }\end{array}$ & $\begin{array}{l}21 \text { countries belong to } \\
\text { Central and Eastern } \\
\text { Europe and the former } \\
\text { Soviet Union for the } \\
\text { period 1992-96. Annual } \\
\text { data. }\end{array}$ & $\begin{array}{l}\text { Total flows, official flows, } \\
\text { all private flows, FDI, } \\
\text { commercial debt flows, } \\
\text { portfolio flows, and short- } \\
\text { term flows. }\end{array}$ & $\begin{array}{l}\text { GF: 6-month LIBOR and economic growth in } \\
\text { OECD. DF: GDP growth, inflation, fiscal balance, } \\
\text { private savings, lag change in reserves, dummy for } \\
\text { countries likely to become EU members, nominal } \\
\text { interest rate minus rate of change of nominal } \\
\text { exchange rate, and domestic credit growth. }\end{array}$ & $\begin{array}{l}\text { Panel analysis was used (fixed effects and common } \\
\text { intercept). Generally movements in flows are } \\
\text { influenced more by fundamentals than GF. EU dummy } \\
\text { was found significant in driving total flows and FDI. } \\
\text { The interest rate variable was not significant in any of } \\
\text { the } 7 \text { definitions of flows. Reforms appear to be the } \\
\text { most important force in driving flows. }\end{array}$ \\
\hline
\end{tabular}


Our emphasis, thus far, has been on the different ways monetary policy contributes to spur or deter investment. We have discussed one of the causes of inflation in Africa-namely wars and civil conflict-but there are other causes for high and chronic inflation in the region that merit discussion. The next section focuses on the issue of fiscal dominance, which seems to be a promising explanation of why inflation has been difficult to tame in many of the countries in the region.

\section{Fiscal Dominance and Inflation}

In most of the world, and throughout most of history, episodes of very high inflation have almost invariably arisen out of situations of broader macroeconomic and political instability. Governments desperate to finance large fiscal deficits will turn to the printing presses to finance expenditures. Large and uncontrolled fiscal deficits occur for many reasons but political instability of some form is surely the leading cause. Inflation taxation is nothing new; even in Roman times, it was a standard technique to shave precious metal coins and recycle them in smaller form. Governments would also debase the currency by diluting the precious metal content of coins and by changing their metal content altogether. The advent of the modern printing press, for better or for worse, vastly improved the technology for generating inflation.

When the government is starved for resources and lacks sufficient taxation alternatives, it is obvious that the need to finance fiscal deficits leads to monetary expansion and inflation. An absolutely critical question, however, in assessing a monetary regime is to ask under what conditions monetary expansion and inflation policy can be separated from fiscal policy. Again, it is useful to frame the debate in the context of modern monetary policy among industrial countries. In academic circles, there is currently a significant debate over whether "fiscal dominance" may be the rule, rather than the exception, even in low-inflation industrial countries. The subtle difference from the canonical case of a poor high inflation country, however, is that inflation is leveraged on a much higher base of nominal debt, including not only currency but nominal government debt. Sargent and Wallace (1981), in their classic article "Unpleasant monetarist arithmetic," first stressed how, even in countries with apparently strong monetary institutions, rising and uncontrolled government budget deficits can arguably feed back quickly into inflation if agents expect that someday monetary independence will snap under the burden of rising government debt. In theory, expectations of future money growth can be so large as to lead to high inflation immediately, overwhelming the efforts of the central bank to attain monetary tightness.

Recently, the Sargent-Wallace argument has been sharpened into "The fiscal theory of the price level" (Leeper, 1991; Sims; 1994; and Woodford, 1994.) The basic argument is that one can always write the government's intertemporal budget constraint as 
EQUATION 1: (Nominal government debt)/price level $=$

\section{The present value of real government taxes (including the inflation tax) minus the present value of real government expenditures}

Equation (1) simply states that the present value of the government's future surpluses, including the inflation tax, must equal the real value of its debt (nominal debt over the price level.) For simplicity, we have simplified by looking at a certainty equivalent formulation. In reality, of course, the right-hand side of equation (1) would actually correspond to a function of the expected value of future government surpluses, which are uncertain. Equation (1) has to hold if the government is solvent; if the real value of expected future surpluses were less than the real value of the debt, the market value of the debt would have to drop immediately, which could be effected by an increase in the price level. (Things are a bit trickier in a sticky-price world where bonds would temporarily sell at discount, but in the long run prices would adjust and the story is the same.) If people expected that the government would never run surpluses, they would never voluntarily hold government debt except for money needed to finance transactions. Of course, in many developing countries, domestic banks are sometimes forced to hold government debt, but in terms of equation (1), forced holding of government debt should be thought of as a way of expanding the taxes that enter on the left hand side.

Equation (1), of course, is nothing new--it is simply a budget constraint that has long been well understood. However, in the traditional literature on industrial countries, it was typically assumed that the path of the price level could be determined by monetary policy, via a traditional relationship where

EQUATION 2: Supply of real balances $=$ Nominal money/ price level

$=$ The demand for real money balances

Given the price level and the future path of monetary policy (implied by the monetary authorities prospective as well as current policies), the price level in equation (1) is given. Because today's value of nominal government debt is given by history, the implication is that in order to ensure that equation (1) holds, fiscal policy must adjust, if not today, then in the future. Thus, the implicit assumption is that the monetary authorities never have to capitulate to the fiscal authorities, so that monetary policy is "dominant" in the determination of the price level.

The fiscal theory of the price level challenges this assumption that monetary policy is dominant. Instead, advocates of the fiscal theory of the price level argue that, even in industrial countries, fiscal policy is dominant and it is monetary policy that must adjust. More precisely, monetary policy can adopt an interest rate policy, and the path of prices will adjust. In a flexible price world, the initial price level must therefore adjust to assure that intertemporal budget balance is attained in a manner consistent with the path of primary surpluses (which is exogenous) and the path of interest rates (which is exogenous).

There is considerable debate in the academic literature over whether the fiscal theory of the price level really applies, or whether the traditional view that monetary policy is dominant in 
setting the price level is the correct one. Very recent work has started to focus on whether there is some threshold level debt and fiscal position that will tilt the balance from monetary to fiscal dominance. For the low inflation industrial countries, the evidence appears to suggest that the traditional monetary dominance paradigm is still the correct one. Canzoneri, Cumby and Diba (2001), for example, show empirically that a rise in (an innovation in) the government surplus typically causes a rise in future surpluses and a fall in future government liabilities. The traditional monetary dominant regime offers a simple explanation, namely that shocks that lead to surpluses tend to be positively correlated over time. Thus, a rise in the path of surpluses allows the government to pay down part of the government debt leading to a fall in future liabilities. The fiscal theory of the price level can explain these results also, but the explanation is rather contorted. The rise in surplus today must eventually become negatively correlated with future surpluses, and this negative correlation must be great enough to make the present value of the future surpluses fall (rather than rise), thus leading to a fall in the value of liabilities. (Part of what makes the fiscal theory of the price level so popular among young researchers is precisely the fact that it gives such counterintuitive results.) For industrial countries, there are also other reasons to be skeptical about the fiscal theory of the price level. For example, it can be shown that as long as the path of government real deficits has some self-correcting mechanism, so that deficits decline as debt grows, monetary policy dominance must prevail. For example, the budget and deficit conditions of the Maastricht treaty turn out to be sufficient to ensure monetary dominance, indeed they are much stronger than is necessary. Also, it turns out that in, say, a two country world, it is not logically possible to have the fiscal theory of the price level hold in both countries, provided they have open trade and capital markets (Loyo, 1996).

Although the fiscal theory of the price level may not be empirically relevant for industrial countries outside extreme circumstances, it may be more relevant for emerging-market and developing countries. In particular, the conditions on self-correcting budget deficits needed to ensure monetary dominance may not always hold, so that fiscal domination of the price level becomes theoretically feasible. This is almost certainly the case in very high inflation countries where monetary institutions have little meaningful independence from the central government. Unfortunately, we do not have firm evidence yet on the factors which determine when fiscal dominance occurs, although the factors almost surely include high debt levels. For example, government debt/GDP levels above 200 percent are almost never observed (except in cases of concessional lending), presumably because fiscal dominance comes into play and the real debt level is restrained by inflation and by inflation expectations. Debt levels below 50 percent of GDP, however, may still be a problem in countries that have very weak tax systems. In Table 12 , we present some suggestive evidence on the possible link between debt levels and inflation for African countries for various periods. The simple correlations between overall government debtto-GDP or debt-to-exports mostly go in the right direction. For the CFA franc zone group, these are strikingly high and always statistically significant, irrespective of what sample period or what measure of indebtedness is used. For the non-CFA franc African countries, the results are somewhat more sensitive to the sample and debt measure that is used. There is a strongly significant correlation between debt-to-exports and inflation in the earlier part of the sample which breaks down in the $1990 \mathrm{~s}$ - at the same time that the correlation between debt-to-GDP and inflation is increasing and becoming significant in the more recent period. Figures 8 and 9 show the scatter plots of the underlying data for CFA and non CFA countries respectively. 
Table 12. Inflation and Debt: Is There a Link?

1970-2001

\begin{tabular}{|l|c|c|c|}
\hline & \multicolumn{3}{|c|}{ Correlation of Annual Inflation and Debt/GDP Ratio } \\
\hline Period & $\begin{array}{c}\text { North Africa and } \\
\text { Sub-Saharan Africa }\end{array}$ & CFA Franc Zone & Non-CFA Franc Zone \\
\hline $1970-2001$ & $0.308^{*}$ & $0.950^{*}$ & 0.186 \\
\hline $1990-2001$ & $0.196^{*}$ & $0.898^{*}$ & $0.209^{*}$ \\
\hline $\begin{array}{l}1970-1979,1980-89, \\
1990-2001\end{array}$ & $0.182^{*}$ & $0.669^{*}$ & $0.202^{*}$ \\
\hline $1980-89,1990-2001$ & $0.192^{*}$ & $0.803^{*}$ & $0.216^{*}$ \\
\hline & Correlation of Annual Inflation and Debt/Exports Ratio \\
\hline $1970-2001$ & $0.548^{*}$ & $0.961^{*}$ & $0.518^{*}$ \\
\hline $1980-89$ & $0.414^{*}$ & $0.964^{*}$ & $0.311^{*}$ \\
\hline $1990-2001$ & 0.091 & $0.969^{*}$ & 0.096 \\
\hline $\begin{array}{l}1970-79,1980-89, \\
1990-2001 \text { averages }\end{array}$ & 0.115 & $0.860^{*}$ & 0.137 \\
\hline $\begin{array}{l}1980-89,1990-2001 \\
\text { averages }\end{array}$ & 0.100 & $0.931^{*}$ & 0.115 \\
\hline
\end{tabular}

Source: International Monetary Fund, World Economic Outlook.

\section{Concluding Remarks}

We have presented evidence that major events, such as wars and civil unrest, occur more frequently in Africa than in other regions. We think that the probability of such adverse outcomes has a critical influence on the investment climate. Such disastrous events often bring other evils with them, including high inflation and a higher level of other distortions such as capital controls that help parallel and illegal currency markets thrive. While bouts of high inflation and all-too-frequent currency crashes are not unique to Africa (witness Western Hemisphere's track record in this regard), the level of opaqueness and distortions, as revealed by the persistent prevalence of extremely high parallel market premia, is a more unique (non-CFA) African phenomenon. In this regard, we believe there are tremendous benefits to be reaped by adopting unified exchange rate regimes broadly throughout the region.

These challenges are, indeed, difficult to overcome, but not insurmountable. Not many years ago, Uganda suffered from all the ills discussed in this paper: war, high inflation, frequent collapses in its currency, and dual markets with a parallel market premia that hit 567 percent in 1988. The end of the war was, of course, the most critical change. But macroeconomic stabilization has brought inflation down to below 5 percent, growth has sharply rebounded, and FDI has risen from zero to more than 4 percent of GDP. With stabilization came the end of dual 
markets and increasing transparency - at time of this writing the Ugandan shilling is one of the more convertible currencies in sub-Saharan Africa. Nor is the strong performance by Uganda unique in the region. As discussed in the most recent World Economic Outlook, countries like Benin, Botswana, Burkina Faso, Cameroon, Mali, Mauritius, Mozambique, Senegal, and Tanzania have been consistently strong performers in recent years, both in terms of their macroeconomic policies and growth performance. While some of these countries have experienced an increase in FDI in recent years, unfortunately not all of them have-which highlights how much persistence and consistency it takes to build an attractive investment climate. Nevertheless, a unified exchange rate regime (or at least very low parallel premia) is a key element in a transparent macroeconomic framework, and would help produce many beneficial side effects in terms of improving governance and reducing corruption. 
Figure 1. U.S. Monetary Policy and Capital Flows to Emerging Market Economies:

Net Real Private Direct Investment

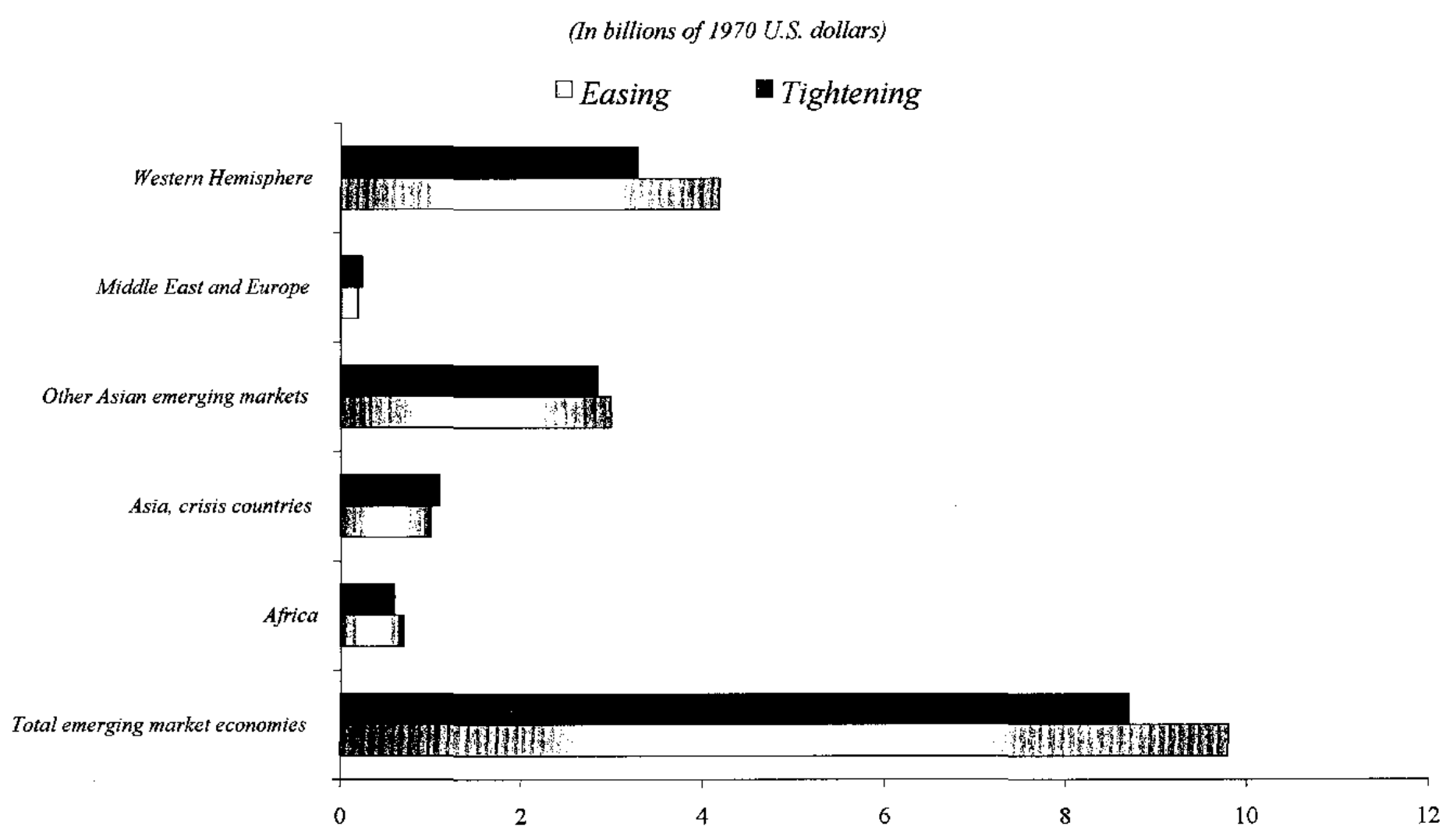

Source: Reinhart and Reinhart, 2001. 
Figure 2. GDP Growth: World and G-7

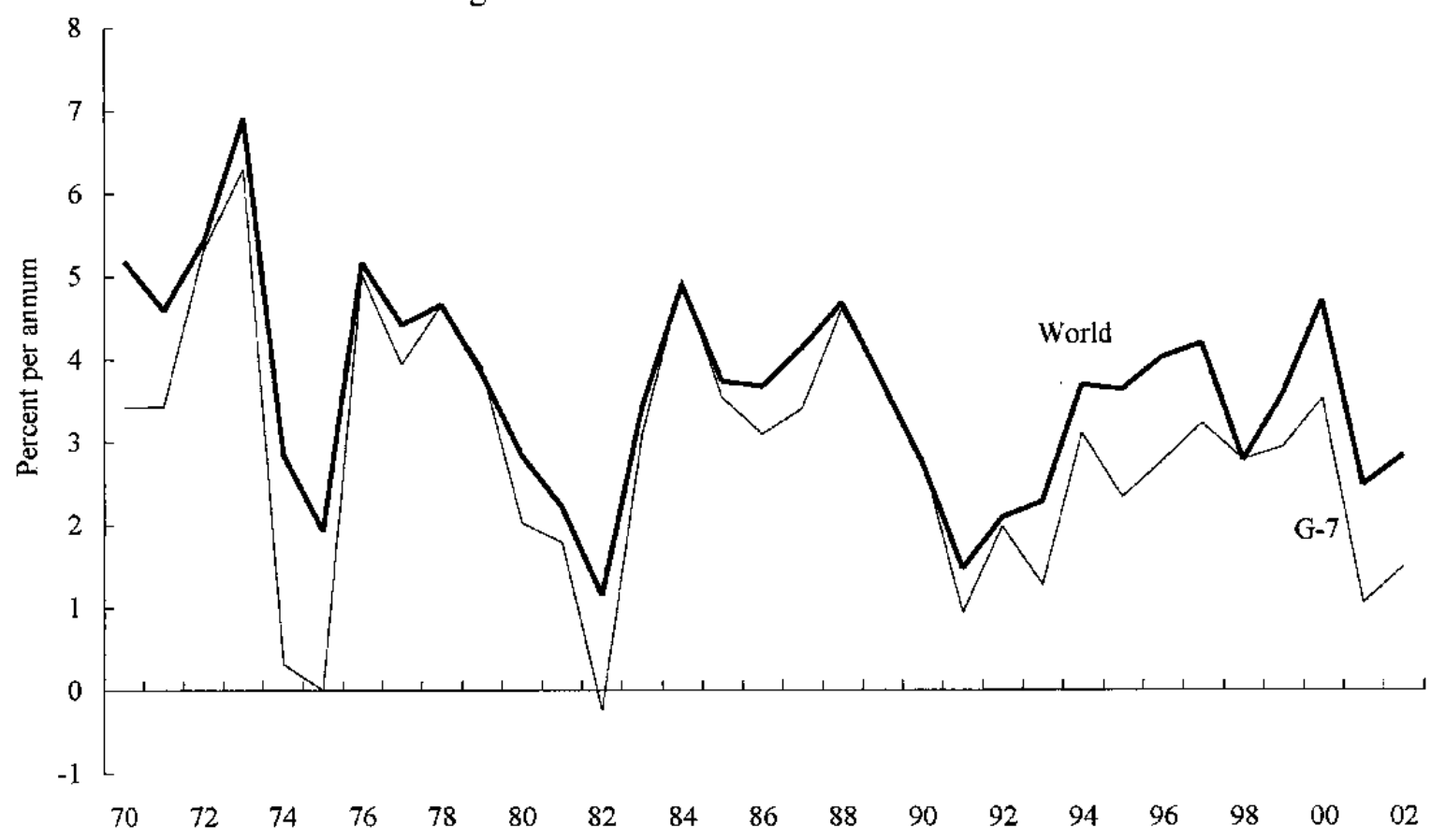

Source: International Monetary Fund, World Economic Outlook. 
Figure 3. Africa: Inflation vs. Foreign Direct Investment (FDI) Inflow, 1970-2001

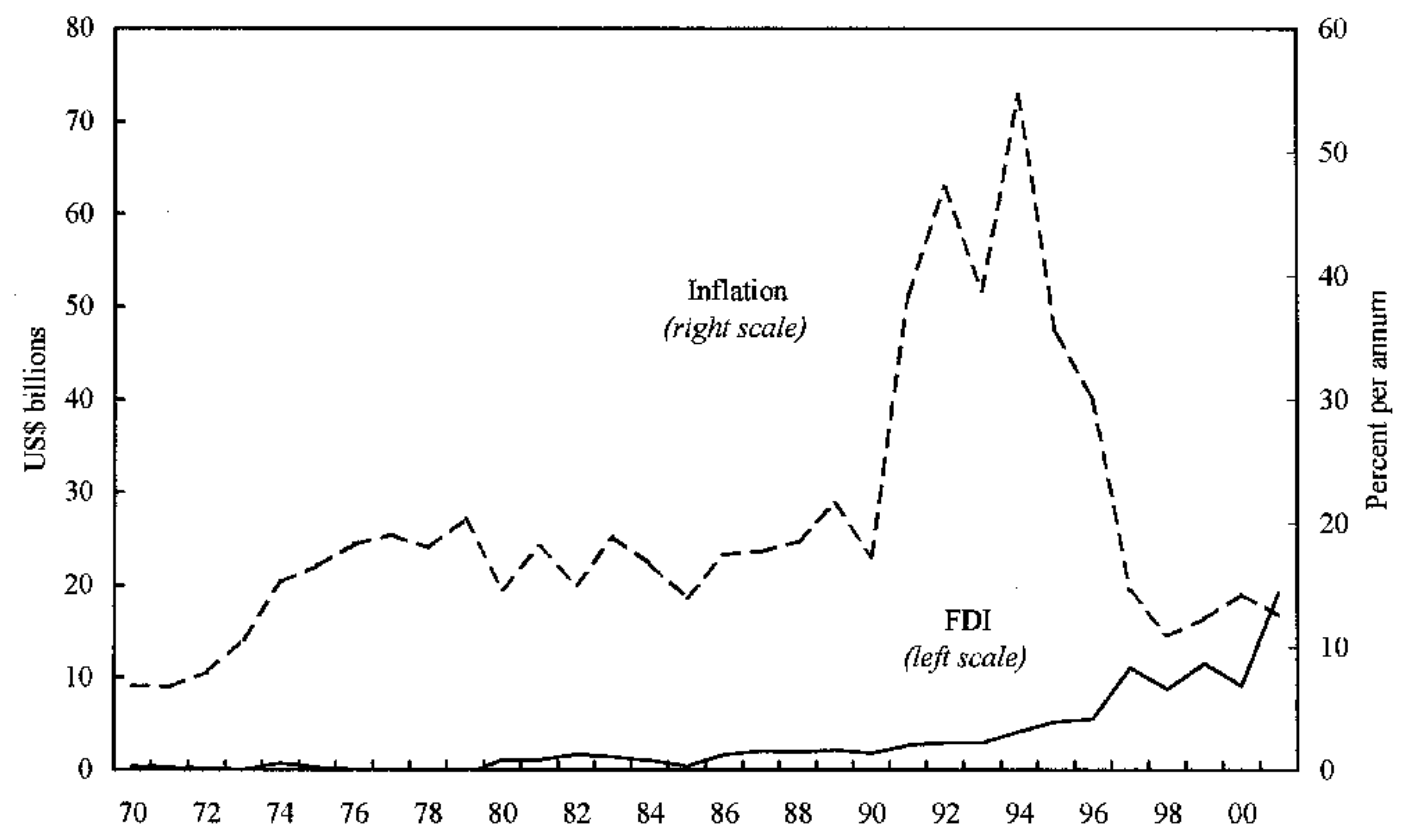

Figure 4. Western Hemisphere: Inflation vs. Foreign Direct Investment (FDI) Inflow, 1970-2001

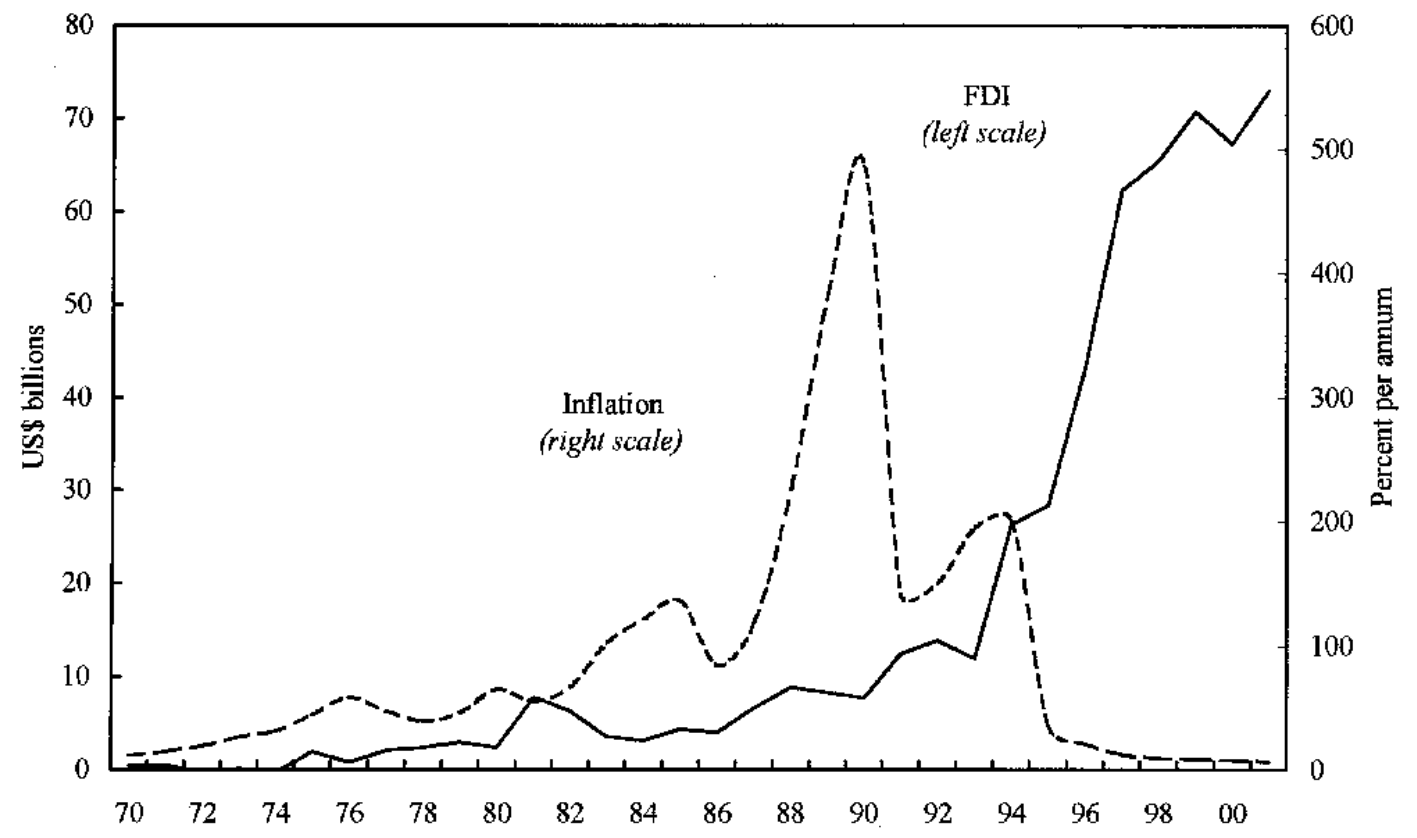

Source: International Monetary Fund, World Economic Outlook. 
Figure 5. Percent of Months in Which the Parallel Market Premia was Above 50 percent: $1979-98$

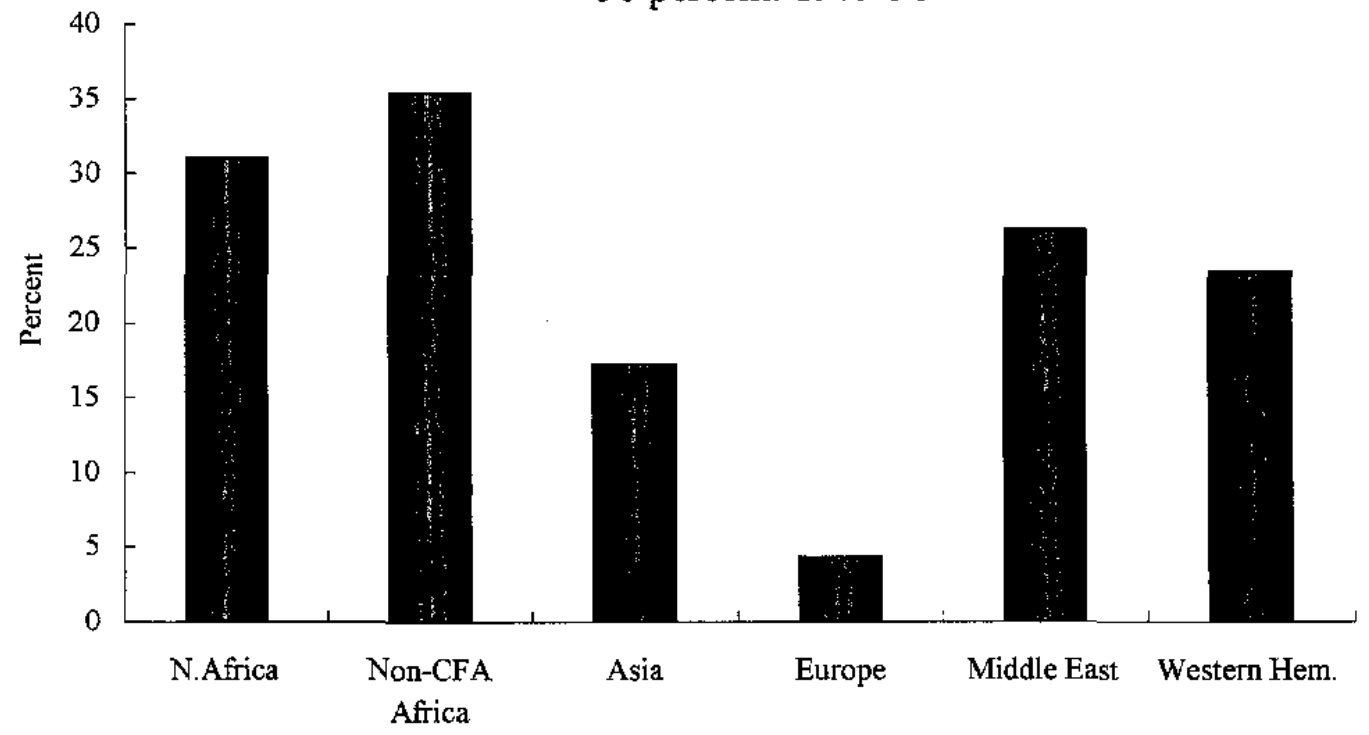

Figure 6. Percent of Months in Which the Parallel Market Premia was Above 500 percent: $1979-98$

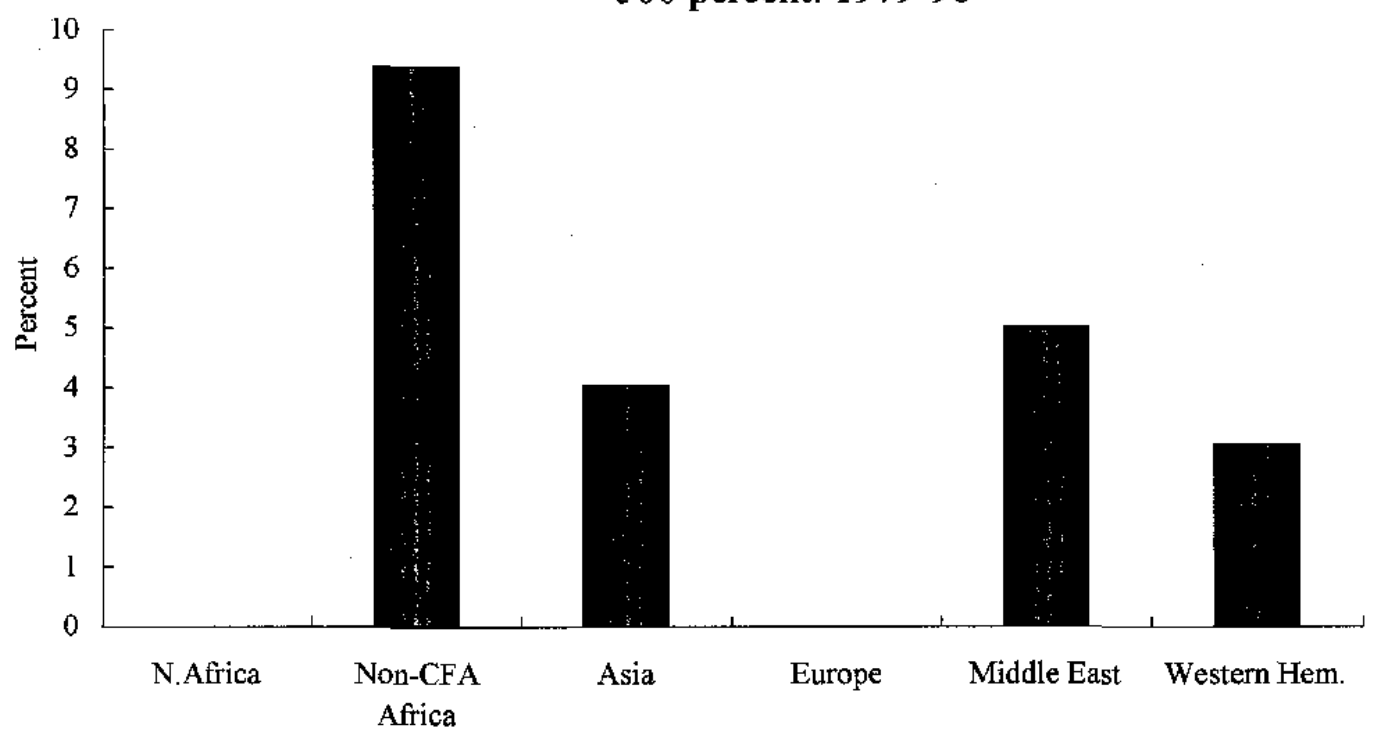

Sources: International Monetary Fund, Annual Report on Exchange Arrangements and Exchange Restrictions and International Financial Statistics; Pick and Sedillot (1971); International Currency Analysis, World Currency Report, various issues; and authors' calculations. 
Figure 7. Inflation and High Parallel Market Premia

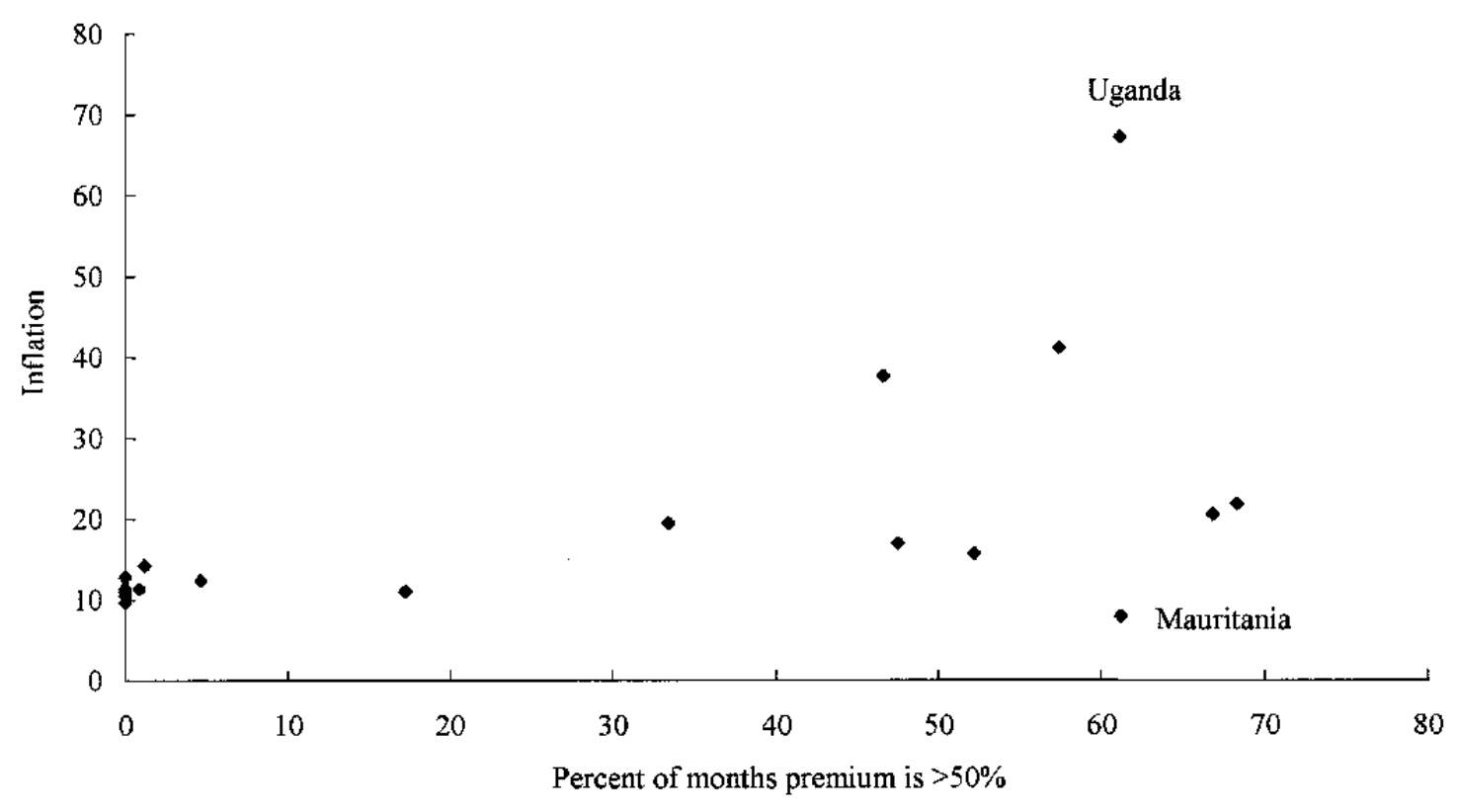

Sources: International Monetary Fundlunual Report on Exchange Arrangements and Exchange Restrictions and International Financial Statistics; Pick and Sedillot (1971); and International Currency Analysis, World Currency Report, various issues. 
Figure 8. CFA Franc Zone

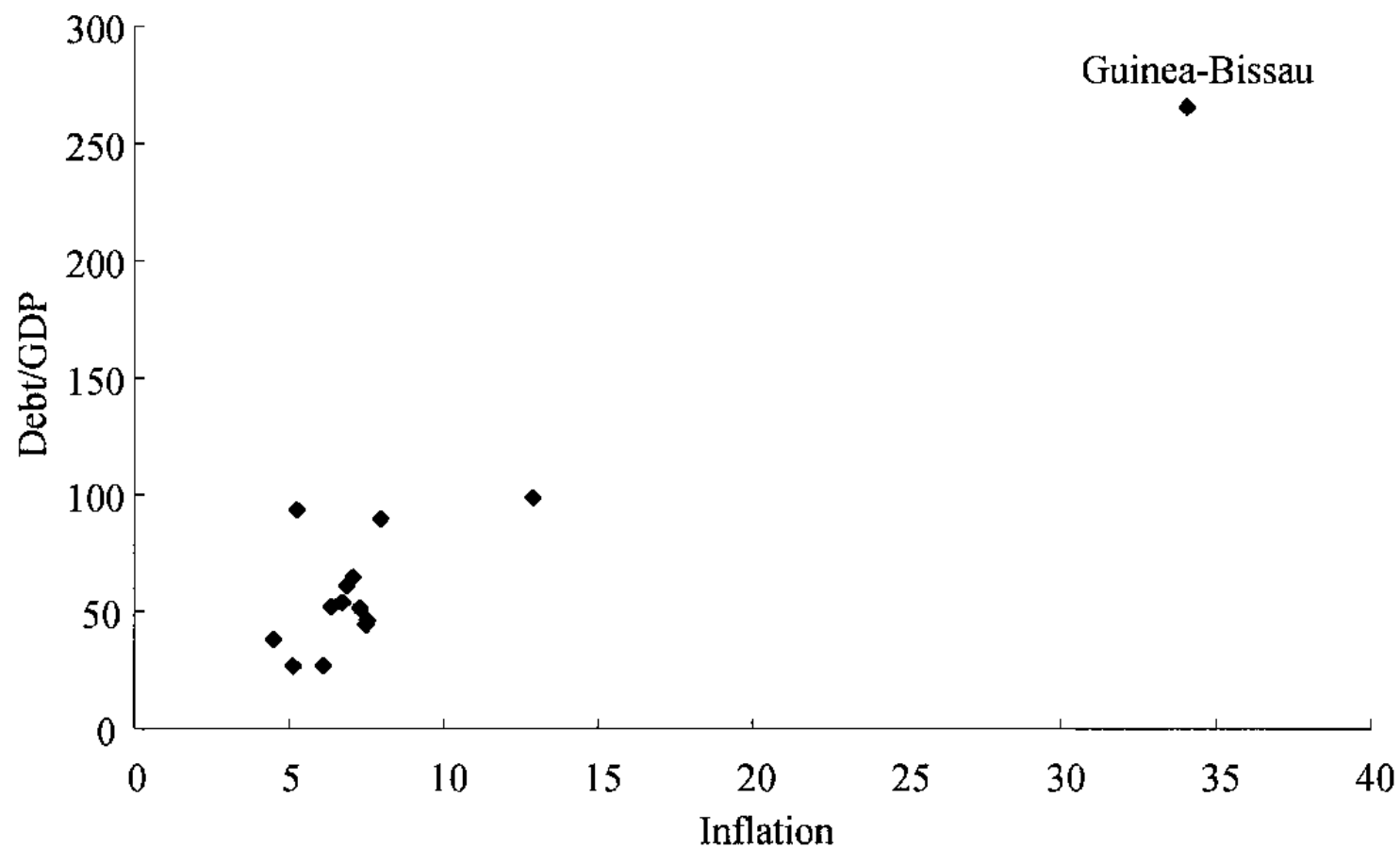

Figure 9. Sub Saharan Africa ${ }^{\mathrm{l}}$

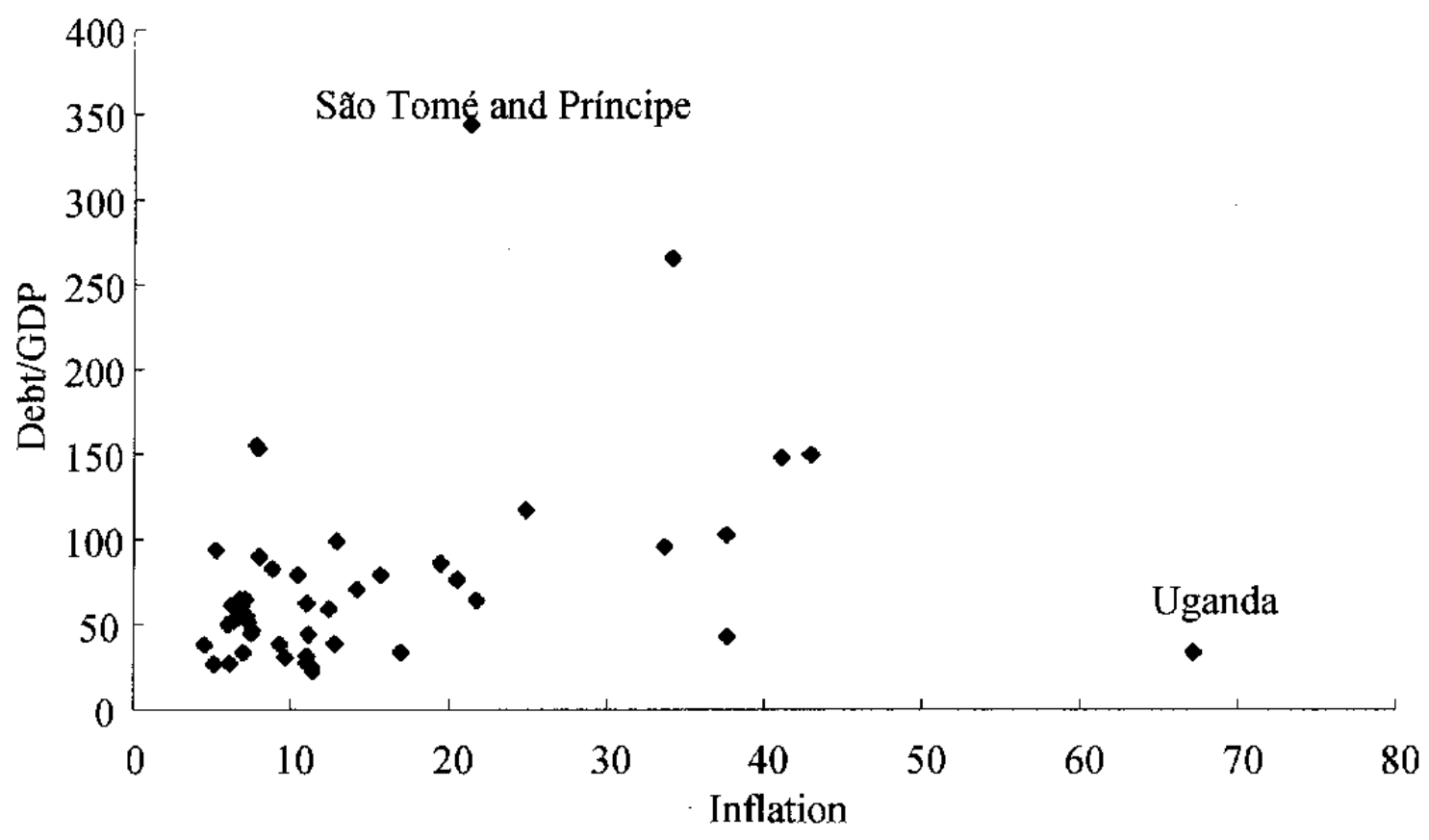

Source: International Monetary Fund, World Economic Outlook.

${ }^{1}$ Excludes the Democratic Republic of the Congo) 


\section{The Cost of Inflation}

Is inflation by itself such a problem? The answer is almost surely yes, but economists' theoretical and empirical evidence on the question is remarkably thin. Because high inflation so seldom occurs in isolation from other macroeconomic problems, time series or cross-country regressions that show a cost of inflation on growth or output are not always convincing, since it is difficult to hold everything else constant. For inflation rates over 40 percent per annum, there does seem to be evidence that growth is retarded (see Easterly, 2001 and Reinhart and Rogoff, 2002). For lower inflation rates, below 40 percent, the evidence is more limited. This is not to say that a country that has an inflation rate of 10 percent is not clearly better off than a country with an inflation rate of 20 percent, and that a country with an inflation rate of 2 percent is not better off than one with 10 percent. The general reduction in inflation rates that has taken place across much of the world over the past ten to twenty years has almost surely been a factor in raising global growth and increasing macroeconomic stability. Recall again Figure 2 of the text, which gives annual growth rates both for the world (using PPP weights) and for the G-7 group of countries. Visually, the decrease in volatility of output growth since the mid-1980s is striking. Not all countries have enjoyed the same improvement in macroeconomic stability over this period. The United States has enjoyed a particularly large drop in output volatility since the mid1980s (see Stock and Watson, 2002), whereas output volatility for Germany appears to have remained roughly constant (reflecting no doubt German unification in 1991) and for Japan, it has actually increased (an outgrowth of the bursting of the asset price bubble in the early 1990s, and a reduction in trend productivity growth.) But, for most countries, increasing monetary stability has been accompanied by increased output stability. The casual evidence presented in Figure 2 may or may not stand up to careful statistical testing; that is not our purpose here. But it is evidence of a broad trend that has helped persuade many that increasing monetary stability does pay off, even at lower levels of inflation.

At a theoretical level, it has taken even longer to assess why inflation matters, especially if it is stable and anticipated. Fischer and Modigliani (1977) is an early attempt to try to catalogue all the various and sundry theoretical costs of inflation. Their basic conclusion is that the main costs of stable and perfectly anticipated inflation are the "shoe-leather costs," that is, the costs to people of having to economize on their holdings of (real) currency balances in order to minimize their share of the inflation tax. The costs of unanticipated inflation are much greater, particularly in a world of imperfect information and imperfect indexing. Keynes (1936), of course, argued that in the real world, indexing of wages and prices to inflation is very limited (at low to moderate levels of inflation), so that monetary volatility translates directly into variability in output and employment. Though economists have made little progress in understanding exactly why nominal rigidities are so important, Keynes' basic insight is very much alive today. There is a broader question of why, even in today's hyper-sophisticated (indeed hyperactive) financial markets, there is not greater capacity to index to inflation. Absent such indexation, and given long-term nominal contracts, then uncertain inflation is quite harmful to economic activity, making investment planning difficulty, and making it difficult to continuously maintain full employment (or whatever the modern search-theory equivalent of full employment is). The government is possibly the greatest source of nominal rigidities in the economy. Tax systems, 
especially, have important nonneutralities. Some are well known, for example, if tax rates are increasing in income, then inflation will raise average tax levels. If taxes take significant amounts of time to collect, then rises in the rate of inflation can lower effective real tax rates, if agents are able to pay the government with a lag in depreciated currency. Many governments tax nominal rather than real interest receipts.

All of these are fairly primitive failures of indexation. Feldstein (1998) has emphasized that the effective rate of capital taxation-which is enormously complicated to calculate in practice - can be very sensitive to inflation rates even at low levels. For example, even starting from an inflation rate as low as 2 percent, a 1 percent reduction in inflation might raise the capital stock as much as 3 percent, according to Feldstein's calculations. In principle, this problem could be solved via adequate indexation of the corporate income tax. In practice, the accounting issues are so complicated that it is much easier to deal with the problem by simply having a lower rate of inflation. This last example is particularly interesting because it highlights how, in the complex modern world, the distinction between high inflation and variable inflation is not as sharp as one might think. When one looks at corporate accounting and taxation, inflation can lead to problems even if when it changes only very slowly, since it is so costly to adapt capital taxation and depreciation rules adequately to compensate.

The more important distinction, for our purposes here, is to distinguish between the effects of inflation in isolation from other forms of macroeconomic instability (e.g., if a modern industrial country central bank mistakenly, and temporarily, adapts an inefficient control technique), from the costs of inflation instability in a country where the government has a shorttime horizon and where inflation is accompanied by numerous other macroeconomic problems. The latter is almost surely the typical case in most countries where inflation is over 40 percent. 
Table 13. Currency Crashes: North Africa and CFA Franc Zone Countries, 1965-2001

\begin{tabular}{|l|c|c|c|}
\hline \multicolumn{1}{|c|}{ Country/Group } & Dates of Severe Currency Crashes & $\begin{array}{c}\text { Number of } \\
\text { Severe Crashes }\end{array}$ & $\begin{array}{c}\text { Total Number of Crashes } \\
\text { Including Severe Crashes }\end{array}$ \\
\hline North Africa & & & \\
\hline Algeria & $1991: 1,1991: 9,1994: 4$ & 3 & 0 \\
\hline Morocco & & 0 & 0 \\
\hline Tunisia & & 1 & 1.33 \\
\hline Average for the region & & & 1 \\
\hline Sub-Saharan Africa CFA & $1994: 1$ & 1 & 1 \\
\hline Benin & $1994: 1$ & 1 & 1 \\
\hline Burkina Faso & $1994: 1$ & 1 & 1 \\
\hline Cameroon & $1994: 1$ & 1 & 1 \\
\hline Chad & $1994: 1$ & 1 & 1 \\
\hline Central African Republic & $1994: 1$ & 1 & 1 \\
\hline Congo, Republic of & $1994: 1$ & & \\
\hline Cote d'Ivoire & & 1 & 1 \\
\hline Equatorial Guinea & $1994: 1$ & 1 & 1 \\
\hline Guinea-Bissau & $1994: 1$ & 1 & 1 \\
\hline Mali & $1994: 1$ & 1 & 1 \\
\hline Niger & $1994: 1$ & 1 & 1 \\
\hline Senegal & $1994: 1$ & 1 & 1 \\
\hline Togo & & 1 & 1 \\
\hline Average for the region & & 1 & 1 \\
\hline Notes: Two definion & & 1 & 1 \\
\hline
\end{tabular}

Notes: Two definitions of currency crashes are used. A severe currency crash refers to a 25 percent or higher monthly depreciation which is at least 10 percent higher than the previous month's depreciation. The "milder" version represents a 12.5 percent monthly depreciation which is at least 10 percent above the preceding month's depreciation. To put in perspective the monthly depreciations annualized are 1,355 percent and 310 percent respectively. 
Table 14. Currency Crashes: Sub-Saharan Africa Non-CFA Franc Zone Countries, 1965-2001

\begin{tabular}{|c|c|c|c|}
\hline Country/Group & Dates of Severe Currency Crashes & $\begin{array}{c}\text { Number of } \\
\text { Severe Crashes }\end{array}$ & $\begin{array}{l}\text { Total Number of Crashes } \\
\text { Including Severe Crashes }\end{array}$ \\
\hline Angola & $\begin{array}{l}1991: 3,1991: 11,1991: 12,1992: 4,1993: 1, \\
1993: 3,1993: 10,1994: 2,1994: 6,1994: 10 \\
1995: 4,1995: 5,1995: 8,1995: 9,1996: 2 \\
1996: 3,1996: 5,1997: 7,1999: 5,1999: 7 \\
1999: 9,2000: 5\end{array}$ & 22 & 25 \\
\hline Botswana & & 0 & 4 \\
\hline Burundi & $1983: 11$ & 1 & 7 \\
\hline Congo, Democratic Rep. of the & $\begin{array}{l}1967: 6,1976: 3,1978: 11,1979: 1,1979: 7, \\
1980: 2,1981: 6,1983: 9,1990: 11,1991: 2, \\
1991: 7,1991: 8,1991: 10,1991: 11,1992: 1, \\
1992: 3,1992: 5,1992: 6,1992: 9,1992: 10, \\
1993: 1,1993: 6,1993: 8,1993: 11,1993: 12, \\
1994: 2,1994: 7,1995: 8,1995: 9,1995: 11, \\
1996: 1,1997: 5,1998: 10,1999: 4,2000: 1, \\
2000: 6,2000: 10\end{array}$ & 37 & 44 \\
\hline Ethiopia & $1992: 10$ & 1 & 1 \\
\hline Gambia, The & $1986: 1$ & 1 & 4 \\
\hline Ghana & $\begin{array}{l}1967: 7,1971: 12,1972: 2,1978: 8,1983: 10 \\
1984: 11,1986: 1,1987: 2\end{array}$ & 8 & 10 \\
\hline Guinea & $1986: 1,1986: 12,1987: 1$ & 3 & 4 \\
\hline Kenya & & 0 & 5 \\
\hline Lesotho & $1985: 8$ & 1 & 6 \\
\hline Liberia & 1998:1 & 1 & 2 \\
\hline Madagascar & $1987: 6,1994: 5$ & 2 & 5 \\
\hline Malawi & $1987: 2,1994: 2,1994: 10,1998: 8$ & 4 & 13 \\
\hline Mauritania & $1992: 10$ & 1 & 2 \\
\hline Mauritius & $1979: 10$ & 1 & 3 \\
\hline Mozambique & $1981: 1,1987: 7,1988: 7,1991: 4$ & 4 & 6 \\
\hline Nigeria & $1986: 10,1989: 1,1992: 3,1999: 1$ & 4 & 7 \\
\hline Rwanda & $1966: 4,1990: 11,1994: 3,1994: 8,1995: 3$ & 5 & 7 \\
\hline Somalia & $\begin{array}{l}1982: 7,1984: 9,1985: 1,1986: 1,1987: 6, \\
1987: 9,1988: 6,1989: 5,1989: 12\end{array}$ & 9 & 11 \\
\hline South Africa & $1985: 8$ & 1 & 6 \\
\hline Sudan & $\begin{array}{l}\text { 1979:9, 1981:11, 1982:11 1985:2, 1987:10, } \\
\text { 1991:10, 1992:2, 1993:11, 1994:7, 1995:9, } \\
\text { 1995:12, 1996:1 }\end{array}$ & 12 & 13 \\
\hline Swaziland & & 0 & 6 \\
\hline Tanzania & $1983: 6,1984: 6,1986: 6$ & 3 & 6 \\
\hline Uganda & $1981: 6,1985: 11,1987: 5,1988: 7,1989: 10$ & 5 & 12 \\
\hline Zambia & $\begin{array}{l}1976: 7,1983: 1,1985: 10,1986: 10,1987: 2, \\
1987: 4,1989: 7,1992: 2,1992: 12,1993: 11 \\
1994: 1,1994: 3,1994: 10,1994: 11\end{array}$ & 14 & 22 \\
\hline Zimbabwe & $1991: 9,1997: 12,2000: 8$ & 3 & 6 \\
\hline Average for the region & & 6 & 9 \\
\hline $\begin{array}{l}\text { Average for the region } \\
\text { excluding hyperinflation } \\
\text { countries (i.e., Angola and } \\
\text { Congo) }\end{array}$ & & 4 & 7 \\
\hline
\end{tabular}

Notes: Two definitions of currency crashes are used. A severe currency crash refers to a 25 percent or higher monthly depreciation which is at least 10 percent higher than the previous month's depreciation. The "milder" version represents a 12.5 percent monthly depreciation which is at least 10 percent above the preceding month's depreciation. To put in perspective the monthly depreciations annualized are $1,355 \%$ and 310 percent, respectively. 
Table 15. Currency Crashes: Asia, and Europe, and Middle East, 1965-2001

\begin{tabular}{|c|c|c|c|}
\hline Country/Region & Dates of Severe Currency Crashes & $\begin{array}{l}\text { Number of } \\
\text { Severe Crashes }\end{array}$ & $\begin{array}{l}\text { Total Number of } \\
\text { Crashes Including } \\
\text { Severe Crashes }\end{array}$ \\
\hline China & 1989:12, 1994:1 & 2 & 3 \\
\hline Hong Kong SAR & & 0 & 0 \\
\hline India & $1966: 6$ & 1 & 3 \\
\hline Indonesia & $\begin{array}{l}1967: 11,1978: 11,1983: 4,1986: 9,1997: 12, \\
1998: 1,1998: 5,1998: 10\end{array}$ & 8 & 12 \\
\hline Korea & $1998: 12$ & 1 & 5 \\
\hline Lao Peoples Dem. Rep. & $\begin{array}{l}1972: 4,1975: 3,1976: 6,1978: 5,1979: 12,1981: 6 \\
1985: 10,1987: 9,1997: 12,1998: 6,1999: 9\end{array}$ & 11 & 15 \\
\hline Malaysia & & 0 & 0 \\
\hline Myanmar & 1975:1 & 1 & 2 \\
\hline Nepal & $1967: 12$ & 1 & 5 \\
\hline Pakistan & $1972: 5$ & 1 & 2 \\
\hline Philippines & $1970: 2,1983: 10,1984: 6$ & 3 & 5 \\
\hline Singapore & & 0 & 0 \\
\hline Sri Lanka & $1977: 11,1998: 5,1998: 7$ & 3 & 6 \\
\hline Thailand & & 0 & 3 \\
\hline Average for the region & & 2.3 & 4.4 \\
\hline Country/Region & Dates of Severe Currency Crashes & $\begin{array}{c}\text { Number of } \\
\text { Severe Crashes }\end{array}$ & $\begin{array}{c}\text { Total Number of } \\
\text { Crashes Including } \\
\text { Severe Crashes }\end{array}$ \\
\hline Egypt & $1979: 1,1989: 8,1990: 7,1991: 3$ & 4 & 4 \\
\hline Iceland & $1967: 11,1968: 11,1975: 2,1983: 5$ & 4 & 13 \\
\hline Iran, I. R. of & $1993: 3,2000: 12$ & 2 & 2 \\
\hline Irag & & 0 & 0 \\
\hline Israel & $1974: 11,1977: 11,1983: 10$ & 3 & 5 \\
\hline Jordan & & 0 & 1 \\
\hline Lebanon & $\begin{array}{l}1985: 1,1986: 1,1986: 5,1986: 11,1987: 3,1987: 7 \\
1987: 8,1987: 10,1990: 8,1990: 8,1990: 10 \\
1991: 1,1992: 7\end{array}$ & 13 & 19 \\
\hline Poland & $\begin{array}{l}1980: 12,1981: 12,1989: 8,1989: 9,1989: 11, \\
1989: 12\end{array}$ & 6 & 15 \\
\hline Romania & $\begin{array}{l}1984: 11,1990.2,1990: 11,1991: 4,1991: 11 \\
1992: 6,1997: 1\end{array}$ & 7 & 13 \\
\hline Saudi Arabia & & 0 & 0 \\
\hline Syrian, Arab Republic & $1988: 1$ & 1 & 1 \\
\hline Turkey & $1970: 8,1978: 3,1979: 6,1980: 1,1994: 4,2001: 2$ & 6 & 9 \\
\hline Average for the region & 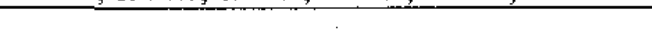 & 3.8 & 6.8 \\
\hline
\end{tabular}

Notes: Two definitions of currency crashes are used. A severe currency crash refers to a 25 percent or higher monthly depreciation which is at least 10 percent higher than the previous month's depreciation. The "milder" version represents a 12.5 percent monthly depreciation which is at least 10 percent above the preceding month's depreciation. To put in perspective the monthly depreciations annualized are 1,355 percent and 310 percent, respectively. 
Table 16. Currency Crashes: Western Hemisphere, 1965-2001

\begin{tabular}{|c|c|c|c|}
\hline Country/Region & Dates of Severe Currency Crashes & $\begin{array}{l}\text { Number of } \\
\text { Severe Crashes }\end{array}$ & $\begin{array}{l}\text { Total Number of } \\
\text { Crashes Including } \\
\text { Severe Crashes }\end{array}$ \\
\hline Argentina & $\begin{array}{l}1967: 3,1975: 3,1975: 61975: 11,1976: 3,1976: 11 \\
1981: 4,1981: 6,1982: 1,1982: 7,1987: 10,1989: 4 \\
1989: 71989: 12,1990: 2,1991: 1\end{array}$ & 16 & 23 \\
\hline Brazil & $\begin{array}{l}1979: 12,1983: 2,1987: 5,1989: 6,1989: 7 \\
1989: 12,1990: 2,1991: 10,1999: 1\end{array}$ & 9 & 15 \\
\hline Bolivia & $\begin{array}{l}1972: 10,1982: 2,1982: 11,1983: 11,1984: 4 \\
1984: 8,1984: 11,1985: 2,1985: 5,1985: 9,1985: 11\end{array}$ & 11 & 12 \\
\hline Chile & $\begin{array}{l}1967: 1,1971: 7,1972: 9,1973: 5,1973: 7,1973: 10 \\
1974: 12,1975: 3,1985: 7\end{array}$ & 9 & 12 \\
\hline Colombia & $1965: 9$ & 1 & \\
\hline Costa Rica & $1974: 4,1981: 1,1981: 10$ & 3 & $\overline{4}$ \\
\hline Dominican Rep. & $1985: 1,1990: 8$ & 2 & 4 \\
\hline Ecuador & $\begin{array}{l}1970: 8,1982: 5,1983: 3,1985: 12,1986: 8,1988: 8 \\
1999: 2,1999: 10\end{array}$ & 8 & 12 \\
\hline El Salvador & $1986: 1,1990: 5$ & 2 & 2 \\
\hline Guatemala & $1986: 6,1990: 8$ & 2 & 3 \\
\hline Guyana & $1987: 1,1989: 4,1990: 6,1991: 2,1999: 3$ & 5 & 9 \\
\hline Haiti & $1991: 9,2000: 9$ & 2 & 3 \\
\hline Honduras & $1990: 3,1990: 4$ & 2 & 2 \\
\hline Jamaica & $1978: 5,1983: 11,1991: 9$ & 3 & 10 \\
\hline Mexico & $1976: 9,1982: 2,1982: 12,1987: 12,1994: 12$ & 5 & 7 \\
\hline Nicaragua & $\begin{array}{l}1979: 4,1985: 2,1986: 1,1988: 2,1988: 6,1988: 8 \\
1988: 10,1988: 11,1989: 1,1989: 6,1990: 4 \\
1990: 5,1990: 8,1990: 12,1991: 3\end{array}$ & $\overline{15}$ & 16 \\
\hline Panama & & 0 & \\
\hline Paraguay & $1984: 3,1984: 6,1985: 3,1986: 12,1989: 3$ & 5 & 5 \\
\hline Peru & $\begin{array}{l}1967: 9,1976: 6,1977: 10,1987: 10,1987: 12 \\
1988: 9,1988: 11,1989: 1,1990: 3,1990: 8\end{array}$ & 10 & 15 \\
\hline Suriname & $1994: 7,1994: 10,1999: 1,2000: 10$ & 4 & 6 \\
\hline Uruguay & $\begin{array}{l}1965: 3,1965: 10,1967: 11,1968: 4,1972: 3, \\
1982: 11,1982: 12\end{array}$ & 7 & 9 \\
\hline Venezuela & $1984: 2,1986: 12,1989: 3,1994: 5,1995: 12,1996: 4$ & 6 & 6 \\
\hline Average for the region & & 6 & 9 \\
\hline $\begin{array}{l}\text { Average for the region } \\
\text { excluding hyperinflation } \\
\text { countries (i.e., Argentina, } \\
\text { Brazil, and Nicaragua) }\end{array}$ & & 5 & 7 \\
\hline
\end{tabular}

Notes: Two definitions of currency crashes are used. A severe currency crash refers to a 25 percent or higher monthly depreciation which is at least 10 percent higher than the previous month's depreciation. The "milder" version represents a 12.5 percent monthly depreciation which is at least 10 percent above the preceding month's depreciation. To put in perspective the monthly depreciations annualized are 1,355 percent and 310 percent, respectively. 
Table 17. Incidence of High Parallel Market Premium, Africa 1970-98: North Africa, CFA, and Non-CFA

\begin{tabular}{|c|c|c|c|}
\hline \multirow[b]{2}{*}{ Country/Group } & \multicolumn{3}{|c|}{ Probability that the Parallel Market Premia Exceeds: } \\
\hline & 50 percent & 100 percent & 500 percent \\
\hline \multicolumn{4}{|l|}{ North Africa } \\
\hline Algeria & 92.2 & 73.8 & 0 \\
\hline Morocco & 0 & 0 & 0 \\
\hline Tunisia & 0 & 0 & 0 \\
\hline Average for the region & 31.0 & 24.6 & 0 \\
\hline Sub-Saharan Africa CFA & 0 & 0 & 0 \\
\hline \multicolumn{4}{|c|}{ Sub-Saharan Africa Non-CFA } \\
\hline Botswana & 0 & 0 & 0 \\
\hline Burundi & 17.3 & 0 & 0 \\
\hline Congo, Dem. Rep of the & n.a. & & \\
\hline Gambia, The & 0 & 0 & 0 \\
\hline Ghana & 46.6 & 36.1 & 17.0 \\
\hline Guinea & 52.2 & 41.9 & 11.4 \\
\hline Kenya & 4.6 & 1.2 & 0 \\
\hline Lesotho & 0 & 0 & 0 \\
\hline Liberia & 89.1 & 89.1 & 29.7 \\
\hline Madagascar & 1.2 & 0 & 0 \\
\hline Malawi & 33.5 & 5 & 0 \\
\hline Mauritania & 61.2 & 45.2 & 0 \\
\hline Mauritius & 0 & 0 & 0 \\
\hline Nigeria & 68.3 & 34.3 & 0 \\
\hline South Africa & 0.9 & 0 & 0 \\
\hline Swaziland & 0 & 0 & 0 \\
\hline Tanzania & 66.9 & 46.3 & 1.2 \\
\hline Uganda & 61.3 & 50.4 & 23.5 \\
\hline Zambia & 57.5 & 28.4 & 4.7 \\
\hline Zimbabwe & 28.8 & 17.0 & 3.2 \\
\hline Average for the region & 35.4 & 24.8 & 9.5 \\
\hline
\end{tabular}

Sources: Reinhart and Rogoff (2002); and the original sources cited therein. 
Table 18. Incidence of High Parallel Market Premium, Asia, Europe, and the Middle East: 1970-98

\begin{tabular}{|c|c|c|c|}
\hline \multirow[b]{2}{*}{ Country/Group } & \multicolumn{3}{|c|}{ Probability that Parallel Market Premia Exceeds: } \\
\hline & 50 percent & 100 percent & 500 percent \\
\hline China & 21.9 & 11.2 & 0 \\
\hline Hong Kong SAR & 0 & 0 & 0 \\
\hline India & 8.6 & 0 & 0 \\
\hline Indonesia & 0 & 0 & 0 \\
\hline Korea & 0 & 0 & 0 \\
\hline Lao People's Dem. Rep. & 42.1 & 35.2 & 15.9 \\
\hline Malaysia & 0 & 0 & 0 \\
\hline Myanmar & 100 & 100 & 36.5 \\
\hline Nepal & 14.4 & 0 & 0 \\
\hline Pakistan & 8.9 & 8.1 & 0 \\
\hline Philippines & 0.9 & 0 & 0 \\
\hline Singapore & 0 & 0 & 0 \\
\hline Sri Lanka & 27.1 & 12.7 & 0 \\
\hline Thailand & 0 & 0 & 0 \\
\hline \multirow[t]{2}{*}{ Average for the region } & 17.2 & 12.9 & 4.0 \\
\hline & \multicolumn{3}{|c|}{ Probability that Parallel Market Premia Exceeds: } \\
\hline Country/Group & 50 percent & 100 percent & 500 percent \\
\hline Belgium & 0 & 0 & 0 \\
\hline Iceland & 8.6 & 0.9 & 0 \\
\hline Israel & 4.9 & 0 & 0 \\
\hline Turkey & 3.7 & 0 & 0 \\
\hline Average for the region & 8.2 & 0.2 & 0 \\
\hline Egypt & 59.4 & 31.7 & 0 \\
\hline Iran, I.R of & 65.1 & 59.4 & 29.7 \\
\hline Jordan & 0 & 0 & 0 \\
\hline Lebanon & 0.9 & 0.3 & 0 \\
\hline Saudi Arabia & 0 & 0 & 0 \\
\hline Syrian, Arab Republic & 58.1 & 50.7 & 5.3 \\
\hline Average for the region & 26.2 & 20.3 & 5.0 \\
\hline
\end{tabular}

Sources: Reinhart and Rogoff (2002) and the original sources cited therein. 
Table 19. Incidence of High Parallel Market Premium, Western Hemisphere 1970-98

\begin{tabular}{|c|c|c|c|}
\hline \multirow[b]{2}{*}{ Country/Group } & \multicolumn{3}{|c|}{ Probability that Parallel Market Premia Exceeds: } \\
\hline & 50 percent & 100 percent & 500 percent \\
\hline Argentina & 32.3 & 15.6 & 0 \\
\hline Brazil & 16.7 & 4.3 & 0 \\
\hline Bolivia & 20.5 & 10.7 & 2.0 \\
\hline Chile & 18.2 & 14.4 & 5.8 \\
\hline Colombia & 0.3 & 0.3 & 0 \\
\hline Costa Rica & 8.9 & 0.3 & 0 \\
\hline Dominican Rep. & 13.3 & 4.0 & 0 \\
\hline Ecuador & 17.0 & 3.7 & 0 \\
\hline El Salvador & 36.3 & 16.1 & 0 \\
\hline Guatemala & 13.8 & 9.6 & 0 \\
\hline Guyana & 43.7 & 36.5 & 12.6 \\
\hline Haiti & 74.9 & 37.7 & 0 \\
\hline Honduras & 29.3 & 2.4 & 0 \\
\hline Jamaica & 16.7 & 5.4 & 0 \\
\hline Mexico & 3.5 & 0.3 & 0 \\
\hline Nicaragua & 39.8 & 31.4 & 18.2 \\
\hline Panama & 0 & 0 & 0 \\
\hline Paraguay & 23.6 & 15.6 & 0 \\
\hline Peru & 32.9 & 7.8 & 1.2 \\
\hline Suriname & 44.7 & 39.4 & 27.4 \\
\hline Uruguay & 6.9 & 2.3 & 0 \\
\hline Venezuela & 22.2 & 15.3 & 0 \\
\hline Average for the region & 23.4 & 12.4 & 3.0 \\
\hline
\end{tabular}

Sources: Reinhart and Rogoff (2002) and the original sources cited therein. 


\section{References}

Calvo, Guillermo and Carmen M. Reinhart, 1999, "The Consequences and Management of Capital Inflows: Lessons for Sub-Saharan Africa," Expert Group on Development Issues Series, 1998:2 (Stockholm: Almqvist and Wiksell International).

Canzoneri, Matthew, Robert Cumby, and Behzad Diba, 2001, "Is the Price Level Determined by the Needs of Fiscal Solvency?" American Economic Review, Vol. 91 (December), pp. 1221-1238.

Collier, Paul and Anke Hoeffler, 2001, "Greed and Grievance in Civil War," (unpublished; Washington: World Bank). ,2002, "Aid, Policy, and Growth in Post-Conflict Countries," unpublished; Washington: World Bank).

Easterly, William, 2001, The Elusive Quest for Growth (Cambridge, Massachusetts: MIT Press).

Fischer, Stanley, and Ando Modigliani, 1978, "Towards an Understanding of the Real Effects and Costs of Inflation," Weltwirtschaftliches Archiv, Vol. 114 (April), pp. 810-33.

Fischer, Stanley, Ratna Sahay, and Carlos A. Végh, 2001, "Modern Hyper- and High Inflations," forthcoming in Journal of Economic Literature.

Edwards, Sebastian, 1990, "Capital Flows, Foreign Direct Investment, and Debt-Equity Swaps in Developing Countries," in Capital Flows in the World Economy, edited by H. Siebert, pp. 255-281 (Tübingen, Germany: J.C.B. Mohr).

International Monetary Fund, 2002, World Economic Outlook (Washington: International Monetary Fund).

Kamaly, Ahmed, 2001, "Behind the Surge in FDI to Developing Countries in the 1990s: An Empirical Investigation," (unpublished; College Park, Maryland: University of Maryland).

Leeper, Eric M., 1991, "Equilibria Under 'Active' and 'Passive' Monetary and Fiscal Policies," Journal of Monetary Economics, Vol. 27 (February), pp. 129-47.

Loyo, Eduardo, 1997, "Going International with the Fiscal Theory of the Price Level," (unpublished; Princeton: Princeton University).

Masson, Paul, and Catherine Patillo, 2001, Monetary Union in West Africa: Is it desirable and How Can it Be Achieved? IMF Occasional Paper 204 (Washington: International Monetary Fund). 
Reinhart, Carmen M., and Vincent R. Reinhart, 2001, "What Hurts Most: G-3 Exchange Rate or Interest Rate Volatility?" in Preventing Currency Crises in Emerging Markets, edited by M. Edwards and J. Frankel (Chicago: University of Chicago Press for the NBER, 2001), pp. 73-99.

Reinhart, Carmen M., and Kenneth S. Rogoff, 2002, "A History of Modern Exchange Arrangements: A Reinterpretation," (unpublished; Washington: International Monetary Fund).

Sargent, Thomas, and Neil Wallace, 1981, "Some Unpleasant Monetarist Arithmetic," Quarterly Review, Federal Reserve Bank of Minneapolis, Vol. 5 (Fall), pp. 1-17.

Sims, Christopher A., 1994, "A Simple Model for Study of the Determination of the Price Level and the Interaction of Monetary and Fiscal Policy," Economic Theory. Vol. 4 No. 3 , pp. 381-99.

Végh, Carlos A., 1992, "Stopping High Inflation," IMF Staff Papers, Vol. 39 (September), pp. 626-95.

Wheeler, David, and Ashoka Mody, 1992, "International Investment Location Decisions: The Case of U.S. Firms," Journal of International Economics, Vol. 33 (August), pp. 57-76.

Woodford, Michael, 1995, "Price Level Determinacy Without Control of a Monetary Aggregate," Carnegie-Rochester Conference Series on Public Policy, Vol. 43 (December), pp. 1-46. 